\title{
Agnihotra Rituals in Nepal
}

\section{Citation}

Witzel, Michael. 2015. "Agnihotra Rituals in Nepal." In Homa Variations: The Study of Ritual Change Across the Longue Durée, eds. Richard K. Payne and Michael Witzel, 371. Oxford: Oxford University Press. doi:10.1093/acprof:0so/9780199351572.003.0014

\section{Published Version}

doi:10.1093/acprof:oso/9780199351572.003.0014

\section{Permanent link}

http://nrs.harvard.edu/urn-3:HUL.InstRepos:34391774

\section{Terms of Use}

This article was downloaded from Harvard University's DASH repository, and is made available under the terms and conditions applicable to Open Access Policy Articles, as set forth at http:// nrs.harvard.edu/urn-3:HUL.InstRepos:dash.current.terms-of-use\#OAP

\section{Share Your Story}

The Harvard community has made this article openly available.

Please share how this access benefits you. Submit a story.

Accessibility 


\section{Michael Witzel}

\section{AGNIHOTRA RITUALS IN NEPAL}

Five" groups of Brahmins reside in the Kathmandu Valley of today: ${ }^{1}$ the Newari speaking Rājopādhyāya, the Nepali speaking Pūrbe, who immigrated in the last centuries before and the Gorkha conquest $(1768 / 9 \mathrm{CE})$, the Kumaĩ, the Newari and Maithili speaking Maithila, and the Bhatțas from South India, who serve at the Paśupatināth temple. Except for the Bhatțas, all are followers of the White Yajurveda in its Mādhyandina recension. It could therefore be expected that all these groups, with the exception of the Bhattas, would show deviations from each other in language and certain customs brought from their respective homelands, but that they would agree in their (Vedic) ritual.

However, this is far from being the case. On the contrary, the Brahmins of the Kathmandu Valley, who have immigrated over the last fifteen hundred years in several waves, ${ }^{2}$ constitute a perfect example of individual regional developments in this border area of medieval Indian culture, as well as of the successive, if fluctuating, influence of the 'great tradition' of Northern India.

Just one aspect of this far-reaching issue shall be studied here in some detail, that is, the various forms of the more important Vedic rituals carried out until today: the daily Agnihotra and the rituals connected with it, such as the fortnightly New and Full Moon sacrifice (dārśapaurṇamāsa) and some related seasonal rituals.

\section{On the history of the Agnihotra in Nepal}

1.1. The Agnihotra, "the casting (of cow milk) into the fire" is a comparatively uncomplicated Vedic sacrifice, but nevertheless, it has at least about a hundred individual actions. ${ }^{3}$ It has to be performed at sunset every night and at sunrise in the morning, actually by all initiated Brahmins who have installed the three holy fires (ahitägni). Its most original purpose certainly was that of a sun spell: ${ }^{4}$ in the evening, the power of the sun enters into the embers of the fire, from where it has to be re-kindled the following morning. The underlying identification of sun and fire is very old, in any case already Indo-Iranian, as is shown by the fire-worship of the Zoroastrians. This is already seen in the Yasna Haptạhāiti, composed in quasi-Zarathustrian Old Avestan. ${ }^{5}$

\footnotetext{
* This paper is a translation of one published in German in 1986; some very limited updating has been carried out, indicated by $<\ldots>$. For additional discussion and interpretation, see Witzel, 1992.

${ }^{1}$ See Witzel 1976: 160; cf. Petech 1958: 186 < update 1984>; more in: Pt. Śikharanāth, Atha Tharagotrapravarāvali, Benares (no date).

${ }^{2}$ More details in Witzel 1977, 1985a; for immigration from Bengal cf. Regmi 1966, vol. IV, inscr. no. 77, from Kashmir (śaivacārya) in c. 1200, from Gujarat in $1216 \mathrm{CE}$, from Maharastra in 1235, from South India (1500/1600), the major influx came from Northern India (eastern Uttar Pradesh, Mithila, Bengal).

${ }^{3}$ Presentation according to the various Vedic schools in Dumont 1939 : 1-33 according to the White Yajurveda (KŚS), in a shorter form in Hillebrandt 1897: 109-111

${ }^{4}$ Cf. ŚB 2.2.4-2.4.1, merely touched on by Bodewitz 1973: 235: 'The symbolism of the Agnihotra'.

${ }^{5}$ Recently, J. Narten 1982: 136 sq., see also her Habilitationsschrift, The Yasna Haptayhāiti, Erlangen 1970.
} 
In early Indian history, the Agnihotra became a popular topic of discussion; especially, the time of the morning offering (before, during, after sunrise) was controversial: in the Upanișads, even Kșatriyas offered their opinion, and in the following centuries the Agnihotra (just like the Aśvamedha) remained a constantly used, standard example of Vedic ritual in texts like the Mahābhārata. During these times, not every initiated Brahmin carried out the rite. On the other hand, it advanced to one that a king must constantly perform with the help of his priest, the (räja)purohita. According to the Atharvaveda Parišișta, a collection of texts whose early parts may have been composed in the centuries around the beginning of our era, the priest must always be an Atharvavedin. ${ }^{6}$ The first late-and post-Vedic descriptions of the Agnihotra and other rites of the royal court are found there; they were to serve the interests of the king and his country. However, the Atharvavedins were mostly not able to enforce this claim, ${ }^{7}$ and therefore the royal priests in Nepal, too, have been -- as far we know of their school affiliation-Mādhyandinas of the White Yajurveda (besides the śaivācāryas).

1.2. Unfortunately, the Agnihotra is not mentioned in early Nepalese inscriptions and texts, but we know that Brahmins settled in Kathmandu valley as early as the Licchavi period ${ }^{8}$ (Changu Narayan inscription, $464 \mathrm{CE}$ ); maybe they had been settled already before 'Kirāta' time or before the so-called 'Gupta' dynasty. At Mātātīrtha, in the west of the valley, they appear as 'leaders' of villages in Licchavi inscriptions. They performed, for example, Aṃśuvarman's Rājābhiṣeka (606 CE, Hāḍigaon-inscr.) and would have carried out his other royal rites as well, with the inclusion of the Agnihotra. ${ }^{9}$ Perhaps the site of this hypothetical Agnihotra was, on the one one hand at Jhul (Mātātirtha) in the west of the valley $^{10}$ (see below, cf. Wright 1972: 158-9.), and later on at the southern rim of the (supposed) palace of Amśuvarman ${ }^{11}$ at Hạdigaon: there, an excavation discovered an Agnikuṇda $^{12}$ next to the Māneśvarī temple. The Kuladevatā (Māneśvarī of the Malla kings) and the Agnikuṇda coincide also elsewhere (see immediately).

The first source for the history of the Nepalese Agnihotra --at any time new sources may appear, ${ }^{13}$ such as in the 3000 unpublished inscriptions of the Malla period $^{14}$-- is a fragmentary inscription from Bhaktapur and the yet to be discussed manuscripts.

\footnotetext{
${ }^{6}$ The age varies in the texts contained therein; some can indicate a terminus post quem of about 140 BCE: first mentioning of Tușāra (= Tukhāra, Toxāristān, possible only after the immigration the Yue-Ji in Bactria. - A royal ritual, for example, is the Pușyābhișeka; cf. M.R. Pant 1977.

${ }^{7}$ See Witzel 1985b, § 11.

${ }^{8}$ For details, see the Witzel 1977: 18, 1985a $§ 4.2$, note 67-68.

${ }^{9}$ See mentioning of Agni in the Hādigaon inscription <Bajracharya 1974: 301>.

${ }^{10}$ See Wright 1972: 159 sq.

${ }^{11}$ See N. Gutchow and Th. L. Manandhar 1977: 83-92; cf. Witzel 1980.

12 See the excavation report by S.B. Deo (1968).

${ }^{13}$ An inscription of Śaiva character is perhaps to be dated around 1400 CE (Regmi 1966, vol. III, no. XXIV), which probably mentions Ānanda (= Ananta) Malla he (1246-1310?), but also a Yaśo-Malla (= Yaksa Malla 1428-1480?) next to a Someśvara, as Kumāra-dīkșita. In line 6, an agnimatha is mentioned. Regmi puts the inscription, probably because paleographical reasons, between one of NS 381 and one of 434; provenance of the inscription is unknown. An Agnihotrin appears in inscription No. XXXIX of South Patan, in Regmi 1966, vol. III (NS 523).

$14<$ For many of them, see now Bajracharya 1999>.
} 
After what has been said so far, it is almost to be expected that this inscription was found in the vicinity of the old palace of Bhaktapur, at Tachapal-Tol in the east of the city. It was a rule always followed in Nepal (and elsewhere, for example in Orissa) that Brahmins were settled south of the palace - before the transfer of the palace to the northwest of the city. In this case it seems to have been the Agnihotri of the king. (Today, the Brahmins again settle south of the palace, just as in Kathmandu, at Om Bahal).

That Agnihotrins existed at Bhaktapur at this early time is shown by a legend reported by Munamkarmi, Mallakälin Nepāl, p. 11: According to this - though historically impossible $^{15}$ the Maithilā king Harisiṃ wo would have established, on his arrival in the Kathmandu valley (1324 CE), the yantra of Talejū Bhavānī at Bhaktapur in the house of an Agnihotri: Taleju appeared to him in a dream and wished that a particularly distinguished location should be found for her. One first looked in the east of the city, at Banelayku, then at Kvāchẽ Tol, and eventually in the house of an Agnihotra Brahman. The king exchanged the latter's piece of land, according his wishes, for another one, and the new place was called Palisachẽ. The legend continues to tell about the expulsion, by the same king Harisimha,of a (another?) Agnihotri, who is described as a great accomplished tantrik. In Bhaktapur tradition, thus, that of a previous Agnihotra is alive and well. This may go back to the time of the still undivided kingdom, the $14^{\text {th }}-16^{\text {th }}$ centuries. (Later on, from about 1600 CE onward, the Agnihotra has only been attested at Patan.)

1.3. From about the same time $(1433 \mathrm{CE})$ comes, the oldest manuscript known to me of this ritual, called Yajurvidhāna: ${ }^{16}$ agnihotra darśapaurṇamāsești sāyamprātarvidhi/śunasīrești, etc., of 33 chapters. Here, the fourtnightly Dārśa-paurnamāa $a$ is the basic form of the description of the Sāyamprātar Agnihotra, a reversal of the normal procedure, where the two are treated separately. The MS is dated in NS 553 śrāvana (= summer of $1433 \mathrm{CE}$ ), and by (or for?) a Soma-Śramaṇa, at Śrī Pitho Bamlānihma Yetā-gṛha. ${ }^{17}$

In addition, there exist two inscriptions at the Agniśālā of Patan, one of which is a very weathered, but nevertheless can be made out to indicate the donation for an annual feeding of Brahmins of all Patan groups (perhaps already dated $1572 \mathrm{CE}$, see below). Hemrāj Śākya ${ }^{18}$ mentions (without a source) a date of 1572 CE for the Agniśāāā.

Then, there are additional MSS, such as one ${ }^{19}$ of NS $701=1601 \mathrm{CE}$, of the famous Rājaguru Viśvanāth Śarmā or V. Upādhya of Patan, who had been attested, so far, only in

\footnotetext{
${ }^{15}$ Cf. Witzel 1976: 172 ff.

${ }^{16}$ The title varies slightly in the chapter colophons; brahmokte yajurvidhāne is constantly recurring; Ms. No. 28 of the Kesar Library, Kathmandu.

${ }^{17}$ The main colophon (some additions still follow): ): samvat 553 srāvaṇa śukle || paurṇamāsī pratipadyā tithau || srāvana pradadhaneșta || ayuṣmayoge || somavā || sampūrṇa || śrīpithobaṃlanihmam yetāgrha \| śrī $x$ x deva soma-śramaṇasya pustakam || likhitam idam || - Bạ̣lanihma also appears later in inscriptions and MSS, probably the same as modern Bolima (see $§ 3.1$ ); $<y e t \bar{a}$-grha is 'southern house'>.

${ }^{18}$ See Pruscha 1975, vol. 2: 137.

${ }^{19}$ Private prosession at Patan, Thyāsaphu, title on the cover: Agnihotra.ya karmma; filmed in 1976 as a test piece (NGMPP), outside the catalogization project; colophon: iti Kātyāyanabhāṣe darśapūrnamāsyā vidhānam samāptam // samvat 717 caitra kṛ̣na dvitūyāyām tithau bṛhaspativāsava. likhita sampūrṇ̣a śrī viśvanātha-śarmaṇā svātmārthe likhitam idam (thus, an autograph of the well-known Rājaguru); additions include: fol.34ff. pañcāgnipavitrārohaṇa (= janai pūrṇimāa); guṇipunimi.yā viśeṣa, indalāpunisi.yā, navānnajavanna.yā, aghrāyana. iṣti, balistotra.
} 
$1638 \mathrm{CE}$ and later on. ${ }^{20}$ This is a Dārśapaurnamāsa-vidhāna (according to the Bhāṣya of the Kātyāyana Śrauta Sūtra). Further there is an approximately simultaneous

Prasādasodaśadamanārohanayajña, a Pavitrārohana etc. In addition there are the modern, yet inaccessible MSS now in use ${ }^{21}$ they are said to go back to a copy of NS 884/9=1683/9 CE (see below). ${ }^{22}$

What is striking is that all of these documents come from the Patan area, where the Agniśālā is located, while the older inscription still was set up at Bhaktapur. Strangely, any testimony about an Agnihotra of the king of Kathmandu ${ }^{23}$ is absent so far. Thus, the presumption arises that the Agnihotra meant for the entire valley had been localized at Patan early on. Both facts agree with the legends that are still told at Patan by the families of the local Agnihotri clans, as well as in Padmagiri's Vamsāvali. ${ }^{24}$ Under the VaiśyaThakuri king Śankaradeva (c. 1065-1082 CE), not only the Kuladevatā of these kings, Tāraṇidevī, would have been established at Kathmandu, ${ }^{25}$ but also the Agnikuṇda at Patan. Wright's Vamśāavali reports the same. However, it also adds (p. 158/159) that some Agnihotrins intermittently emigrated to Gaur (Bengal) after the burning of their village, Jhul -- situated between Kīrtipur and Mātātīrtha-- which thus is again located in the (pre-)Licchavi heartland of the Brahmins. ${ }^{26}$ The wife of one of these Brahmins then fled to Patan (later than $188 \mathrm{CE}$, the alleged date of a manuscript that she took along), and she then lived in Ga(la) Bahal. Her son was a Banrā, thus a Buddhist. This tale combines an original Agnihotra in the west of the valley with the later one at Patan. ${ }^{27}$ Apparently King Śankaradeva was forced to re-found the Agnihotra after the abandonment or conversion to Buddhism by its priests. There is, however, another legend that belongs approximately to the same timeframe.

According to the late Agnihotri Gurujvālānand, the Agnikuṇda of Patan was founded, after the destruction of Hādigaon, <about a thousand years ago $>$ by one Agnihotri who descended from the Manicūḍa mountain, north of Bhaktapur and Changu Nārāyan. He stuck his staff into the sand of the river Nakhu (Prabhāvatī), west of Patan, and took a bath there. ${ }^{28}$ The staff had sprung leaves already by the end of his bath: this is

\footnotetext{
${ }^{20}$ See Regmi 1966, vol. II: 439.

$21<$ I have filmed the MSS in 1985, luckily before the Agnihotri accidentally dropped his Homa MS into the fire; later I found his untainted, original copy among the films of the NGMPP, done at Bhaktapur(! due to marriage relationship) in late 1977. -- Bal Gopal Shrestha (Leiden University) tells me, in his email letter of December 28, 2010 that he too has copied the MSS used at the Agniśālā.>

${ }^{22}$ Private property, Patan; Thyāsaphu, 121 fol., undated; the MSS now in use are kept in the temple, they are already written in Devanāgarī.

$23<$ The Kathmandu Valley, unified under Jayasthiti Malla at the end of the $14^{\text {th }}$ century, was again divided into two, then three kingdoms under his descendants: Bhaktapur, Kathmandu and Patan; the latter was established around 1620, see Burleigh 1976>.

${ }^{24}$ Composed at the beginning of the $19^{\text {th }}$ century, see transl. by Hasrat 1970: 47,

${ }^{25}$ Cf. M.A.J.E. Kiauta 1977.

${ }^{26}$ Compare this with the results of R. Herdick, 1986: $§$ 6: "The region around Kirtipur could have functioned, to some extent, as a 'cultic core area' of the Kathmandu Valley." See Herdick 1986, § 3.1.1 -3.1.4.

${ }^{27}$ See Herdick, 1986: $§$ 6. Transfer of cult objects to the north and west of the Valley; here, it certainly is one to the east.

${ }^{28}$ It is in this area that Kirtipur people think is the origin of the Agini Math (= Agnisālā), see Herdick 1986: $§ 3.1 .2$.
} 
the current Varuṇa ( ${ }^{+}$varana) tree, ${ }^{29}$ the Varuṇa-nāga, in the courtyard of the Agniśālā. The Mitrāvaruṇa figure used in the ritual is made from its wood (see below). At that time, the Nakhu river is supposed to have flowed into the Bāgmati at the place where the Agniśālā is located today.

Certainly various motifs are combined here, for example that of King Maṇicūda of Sāketa, who is said to have given his name to many places in the valley (Hasrat, History, $p$. 12). The Manināga legend is discussed below ( $\$ 2.10)$.

What is surprising in the study of the sources regarding the traditional Agnihotra of Patan is the increasing 'Newarization' of the texts during the last few centuries. The MS of $1433 \mathrm{CE}$ is still completely written in Sanskrit, that of $1601 \mathrm{CE}$ already with Newari insertions; today's MSS have, by and large, Newari 'stage directions' for the individual rituals. Other local influences will be discussed below.

\footnotetext{
${ }^{29}$ According to local information this is indeed a varana tree (Crataevia Roxburghii, 'a tree used in healing and powerful for sorcery that occurs throughout India'; Varuna also called varuna, setu, see Petersburg Dictionary, column 712.
} 


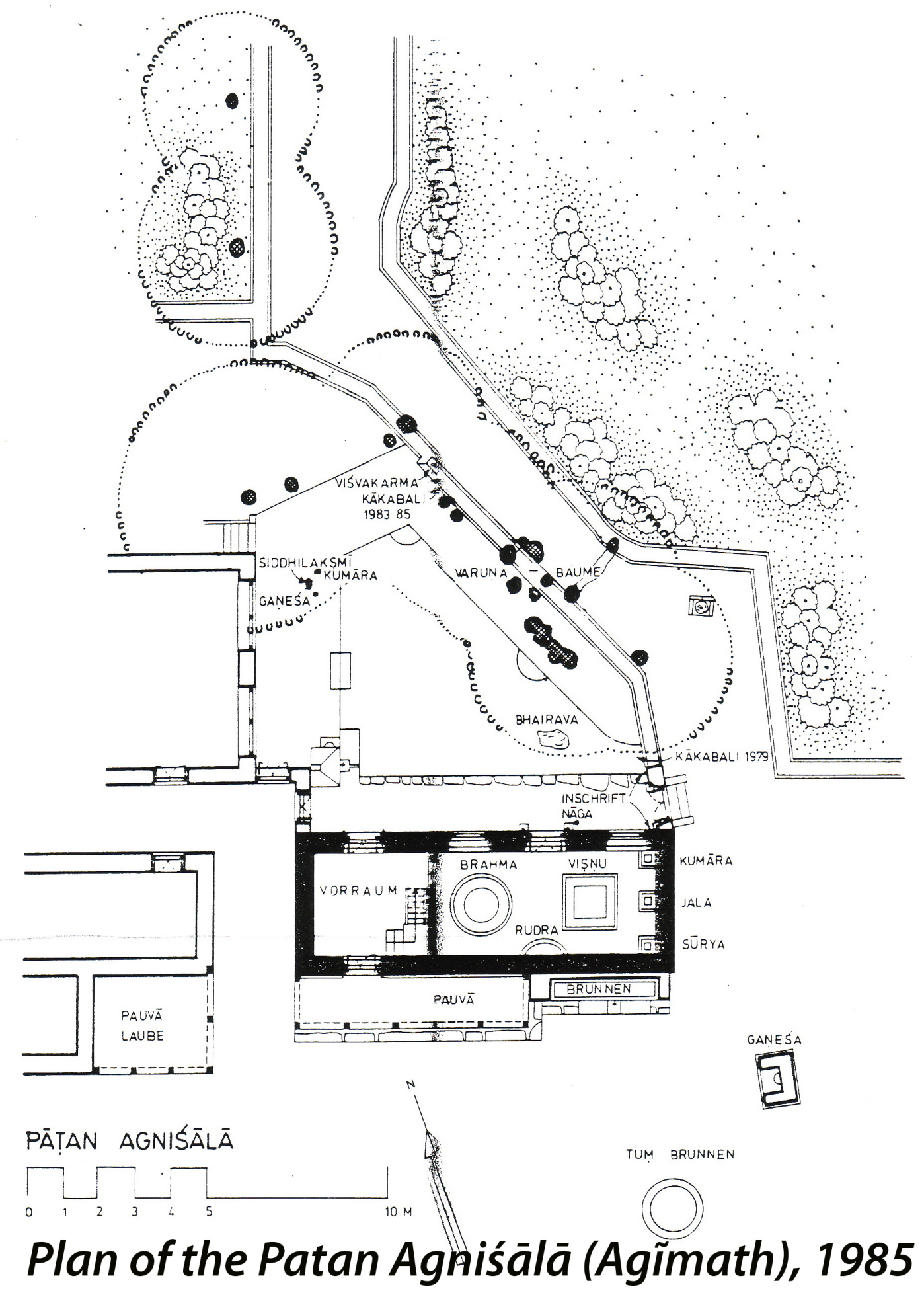

$<<$ INSERT FIGURE: map of Agnimatha.jpg >> 
1.5. Besides the Agnihotra of the Rājopādhyāyas of Patan, three others still exist, two of which are recent revivals by individuals, those of Nārāyaṇa Prasād (a Pūrbe) at Kumārīgal (south of Bodhnāth), Tīrtha Rāj Ācārya (a Pūrbe) at Thamel (north of the center of Kathmandu). Both have taken up the Vedic ritual on their own accord ${ }^{30}$ and both closely follow the Vedic rules of the Kātyāyana Śrautasūtra, although Nārāyaṇ Prasād is said to have visited the Patan Agnihotra as an 'apprentice '. He is also said to have published, with many errors, an Agnisthäpanavidhi. The expenses for his ritual were paid by King Mahendra.

These two revivalist Vedic rituals will not be discussed here any further. Instead, another traditionally performed Agnihotra, that of a Pürbe Brahmin who lives at the southern edge of the Paśupatināth temple (opposite the newly built pilgrims' rest house of the government). His house has an annex for the sacred fires. His family has been performing the ritual for some 200 years on behalf of the current ${ }^{31}$ dynasty: for this, he receives (1974) the sum of Rupees 18,000 per year, ${ }^{32}$ meant for the purchase of wood for the sacred fire, etc.

In India, of course, the Agnihotra is still performed, though not all who call themselves Agnihotri are priests. In many cases the term has become a family name (like Dixit, Vājapeyī/Bajpai, Chaube, Tripathi). These priests cannot be located easily; we always must find out on the spot whether or not there are Agnihotrins. A clue can be, e.g., Kashikar's and Parpola's list of Śrauta rituals of officiating Brahmins ${ }^{33}$ (in: Staal, Agni, 1983). This cannot be discussed here, though a comparison would probably be useful when carried out after the investigation of the Nepalese Agnihotra. Not to be confused with the Agnihotra ritual is the morning and evening homa (sāyamprātar-homa) that is not based on Śrauta ritual; an example is that of the Kashmiri Brahmins ${ }^{34}$ that rests partially on the ritual of the Vedic Kața school, but on the other hand also has been influenced by Śaiva Tantra. This ritual will be adduced later to explain the Agnihotra of Patan. Lastly, the very similar Buddhist homa rituals of the Kathmandu Valley should be pointed out. ${ }^{35}$

\section{The course of the ritual}

2.1. The layout of the offering ground basically is the same in all cases: it concerns the famous 3 Vedic fires: Gārhapatya, Āhavanīya and Dakṣin̄āgni in the west, east and south of the offering ground. Already in the Agnihotra MS of $1433 \mathrm{CE}$ these fires are called: Brahma - Viṣnu, - and Rudra-Kuṇda, after the Hindu Trimūrti. In between the 3 fires there is a dug out, the Vedi, which according to the texts is supposed to have the shape of a woman, 'broad at the shoulders and hips, narrower in the middle. In the Agniśālā of Patan it is missing, but at the New and Full Moon sacrifices grains are strewn out in oval-shape as Vedi / Samudra. - Then, there are the two fires the Sabhya ('hall fire') and the Āvasathya ('guest house fire'), whose use was already controversial in the Vedic texts. If they are

\footnotetext{
$30<$ For similar cases from India see now Witzel, The Present Position of Vedic Śākhās, Proceedings of the $5^{\text {th }}$ International Vedic Workshop, Bucharest 2011 (forthc.) $>$.

$31<$ The monarchy of the Shaha dynasty was abolished by Parliament in 2008; Nepal now is a secular, 'federal democratic republic'>.

$32<$ Then c. US \$7,000>

${ }^{33}$ In Staal 1983, vol. II: 193-251; the Agnihotra von Patan is mentioned on p. 231.

${ }^{34}$ Cf. Witzel, The Veda in Kashmir, Vol. I, ch. II (in preparation).

35 See J. Locke 1980: 103-121; <cf. Witzel 1984a>.
} 
created, they are situated in separate 'sheds' (open halls), each further west of the Gārhapatya fire, in square or or triangular shape. In Paśupatināth, both are found, but in round shape, north (and with Tīrtharāj Ācārya at Thamel even east!), but at Patan under the name Kumāra or Sūrya Kuṇḍa, although in the east but parallel to the Gārhapatya; in addition there is, between the two, an otherwise unknown structure, the Jala Kunda. In the yard in front of the Agniśālā, several additional deities are situated, with aniconic places of worship: a Nāga, the Bhairava stone, the 'Varuna' tree, Viśvakarma and the Sūryavināyaka temple. All Agnihotra forms of the valley share the accommodation of fire in an actual house, not, as is common in Kashmir or in India proper, in a hall open on all sides.

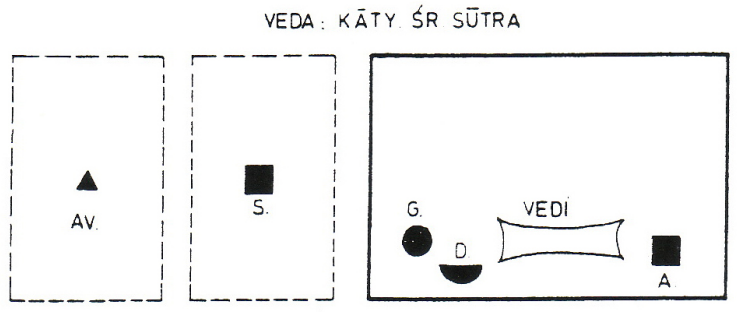

Layout of the Vedic and the four Agnihotras of the Kathmandu Valley
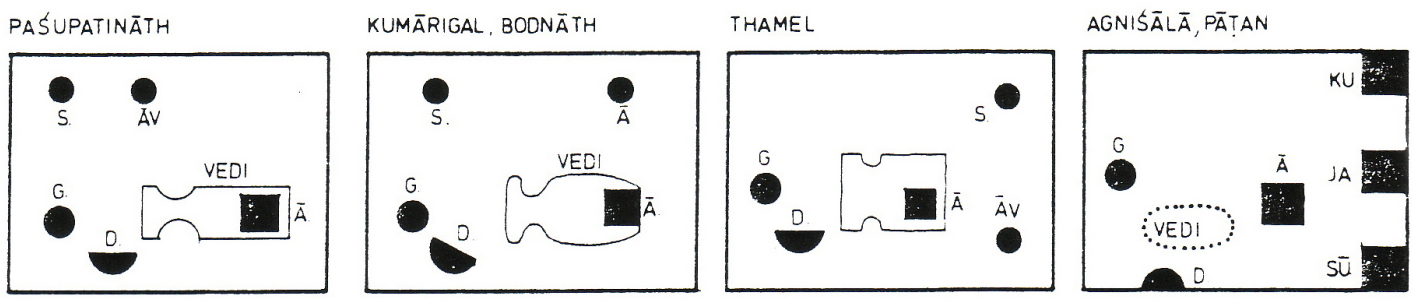

$<<$ INSERT FIGURE: Layout Agnihotras.jpg $>><<$ Insert legend give immediately below:>>

The Five Sacred Fires according to the White Yajurveda (KātyŚrS) and the present condition in the four Agniśāās of Nepal. At Patan a sixth altar, without fire, the jala(vināyaka)kuṇda has been added. The vedi is excavated about $10-15 \mathrm{~cm}$ deep in the mud floor; in Patan it is missing, but is indicated during the New and Full Moon sacrifices by a layer of rice or barley (samudra). Strikingly different from the Vedic norm is the placement of the Vedic dakṣin̄āgni at Patan and Kumārīgal.

G Gārhapatya fire = Brahma Kuṇ̣a (Patan)

D Dakṣiṇāgni fire = Rudra Kuṇḍa

$\bar{A}$ Āhavanīya fire = Viṣnu Kuṇda

$S$ Sabhya fire = Ku. Kumāra Kuṇda

$\bar{A} \bar{A}$ vasathya fire $=$ Sū. Sūrya Kuṇḍa

Ja. Jala Kunḍa 
2.2. The implements used in the rituals are largely consistent with each other in shape and number (for a selection see page 165$)^{36}$ Particularly striking is just the consistent use of the jñānakhadga, the sword of knowledge,' by Agnihotri of Patan; he constantly keeps this pointed piece of wood in his hand, or at least in his clothes. - The Agnihotri of Paśupati seems to own something similar, however, in a much bigger format. It probably is the sphya that appears next to the jñ̄anakhadga also the New / Full Moon sacrifice in Patan. The number of priests and other participants is congruent as well (however, again not the exterior, such as their clothes).

<<INSERT figure “Agnihotra-implements.jpg” about here >>

\footnotetext{
${ }^{36}$ They are very ancient in that they are still made of wood nowadays, just the descriptions in the Vedic texts themselves say, but also -- as D. Schlingloff kindly informs me-- figures at Sanchi show, thus from the last few centuries BCE.
} 


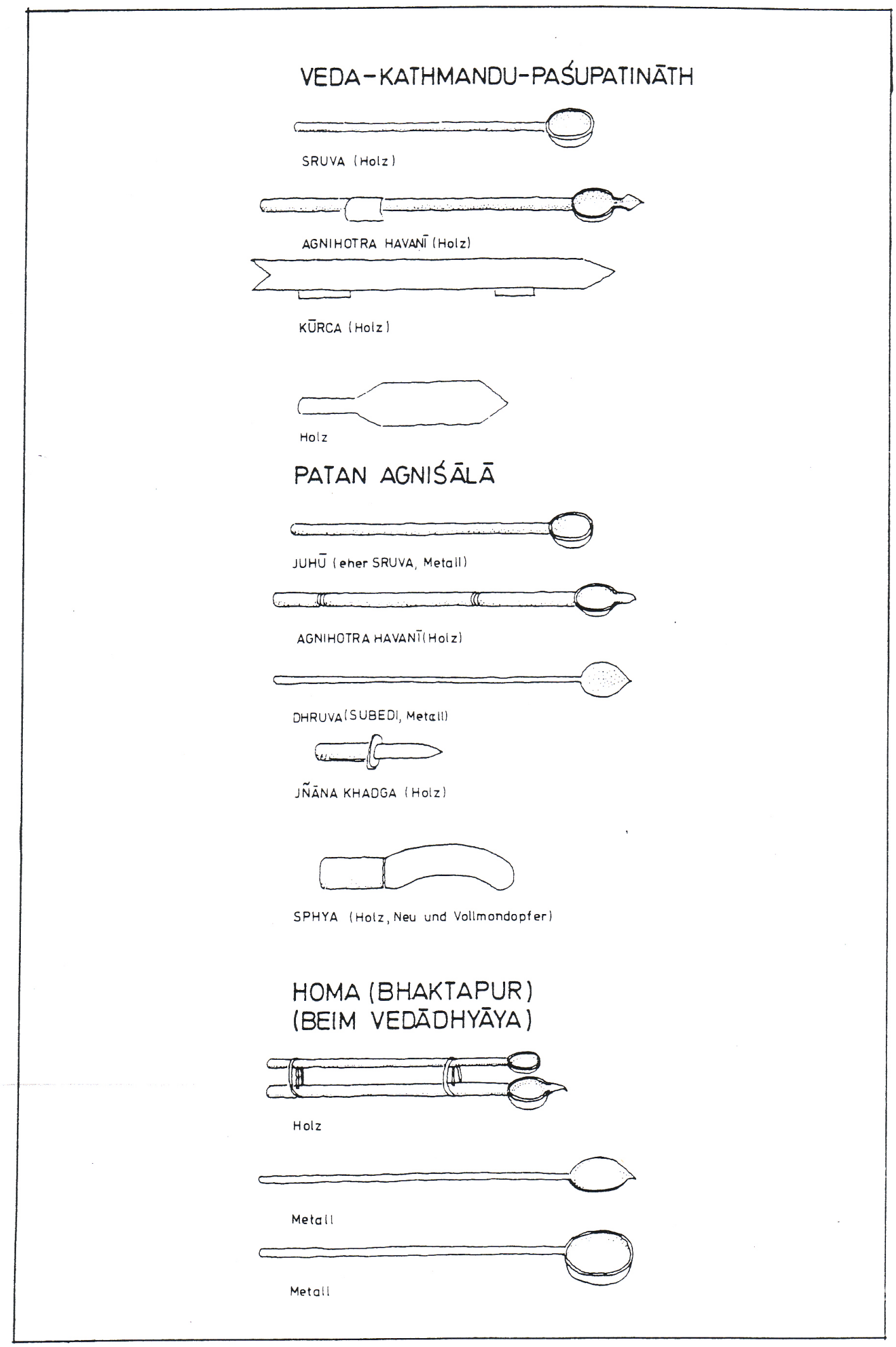

\section{Implements used at the Agnihotras}


2.3. The 'sacrificer' (yajamāna) ${ }^{37}$ and his wife can attend the actual Agnihotra, but they let the rite carried out by a priest. This is certainluy necessary in the Veda, when it concerns as in this present case - a Kșatriya, the king. The sacrificer, however, can also perform the Agnihotra himself if he is a Brahmin.

Now, in Patan and Paśupatināth the king is the actual sacrificer, i.e., that the one who ultimately pays - but he does not appear: the Agnihotri himself is the yajamāna carries out the the ritual for his on benefit and that of the king and the country.

There also are variations in the design of the four Agnihotras regarding the status of the wife of the sacrificer: at Paśupatināth I have never seen her participate; at Thamel, this is done as prescribed in the Vedas; but at Patan she is very active, and for various reasons : on the one hand, she actually must actively assist her husband in the preparation and execution of hundreds of small ritual actions (which is not as necessary with the other Agnihotris, because with them the rite is less complicated; this Vedic ritual has "only" about 100 individual actions); on the other hand, she at Patan she also has true priestly functions, to which we will return (see \$3.3). In their clothes, the Brahmins differ in so far as the Newar Agnihotri, though he puts on the traditional North Indian attire (dhoti, caubandhi) for the ritual just like the others, -- this is, however, sometimes colored red (e.g. at the pratipadā); otherwise white prevails.

2.4. The installation, the observances of the priests, and the time of the offering of the Agnihotra differ as well. The succession of the Agnihotrins of Paśupatināth is governed by family membership; ideally, the son of the late Agnihotri becomes the new priest of this ritual; however, at Patan things are very different. According to Newar custom, it must be the eldest among the groups of Brahmins that supply the Agnihotrins; of course this results in relatively short tenures, and worse, in relative unfamiliarity of the ritual by the successor; though, probably everyone has assisted his relatives as a boy or sometimes even as a young man, this may date back 50 years by the time when the new Agnihotri begins with the ritual.

On the other hand, knowledge of the ritual can at best be acquired by participating in the bi-weekly Dārśapaurṇamāsa rituals: four additional priests must attend (but they almost never appear more so that the Agnihotri and his wife have carry out the duties of all 6 priests simultaneously). The last Agnihotri who died about three years ago $<1982>$ therefore maintained that his real teacher (guru) was the ritual manual, and for that reason he did not allow its filming, as kind as otherwise usually was. He was Agnihotri from 1974 to 1980; his successor, by now no longer the eldest but only the $2^{\text {nd }}$ or $3^{\text {rd }}$ in age ranking, could only be persuaded after a 1 or 2 year break to accept this vocation that is paired with many exertions.

Unlike for the other Agnihotrins very serious observances are imposed on the Patan: he may no longer cross rivers - because he is identical with Agni, the fire god (incidentally, an already Vedic observance for certain consecrated persons - though then

${ }^{37}$ <'Sacrificer' is the traditional Indological translation, though a yajamāna (literally, “one who sacrifices for himself') usually is merely the sponsor of a particular ritual, which is carried out by his Purohita or other priests, as in the present case>. 
only for periods of time); thus, he is limited for the rest of his life to Patan (and its southern outskirts, up to the rim of the valley): in the north, east and west large and small rivers limit the town's area. Furthermore, he must fast much, cannot eat meat or eggs, and must be sexually celibate.

The late, penultimate Agnihotrin who died in 1974, is said to have been quickly harmed in his health after taking up the office, whereas he had previously walked every day for many kilometers (from Patan to Gokarna.) His successor, however, became 92 years old. - The time of the ritual at Paśupati and Patan also differ.

2.5. The Vedic ritual is to take place at the time of sunrise or sunset; the Brāhmana texts are full of discussions about the right point of time: before, during or after sunrise. This rule is usually followed by the Agnihotri of Paśupati, but not that of Patan: the morning Agnihotra takes place sometime in the morning, usually around 10 a.m., but definitely not at sunrise; the evening ritual is very shortened.

The reason for this discrepancy in all likelihood is the current position of the Agnihotra of Patan. It is not a private rite, but widely accessible. About two dozen visitors come not just on their birthdays but even daily. These mostly are women with their püjā plates and all kinds of gifts. This would hardly be possible at 6 a.m. -- The Agnihotrins of Kumārīgal and of Thamel still perform their rituals more or less at the correct time.

\subsection{Pattern of the ritual}

The similarities and differences in the rite are probably best described by a table (see table). Clearly, five main parts can be distinguished in the rite: ${ }^{38}$

$<<$ INSERT DIAGRAM:"'Ritual Structure.jpg" about here , and insert table given immediately below to the left of it; and table "Abbreviations and meanings:" below both $>>$

${ }^{38}$ Cf. H. Krick 1982: 502 f.: Agnihotravrata, for the Vedic situation. 


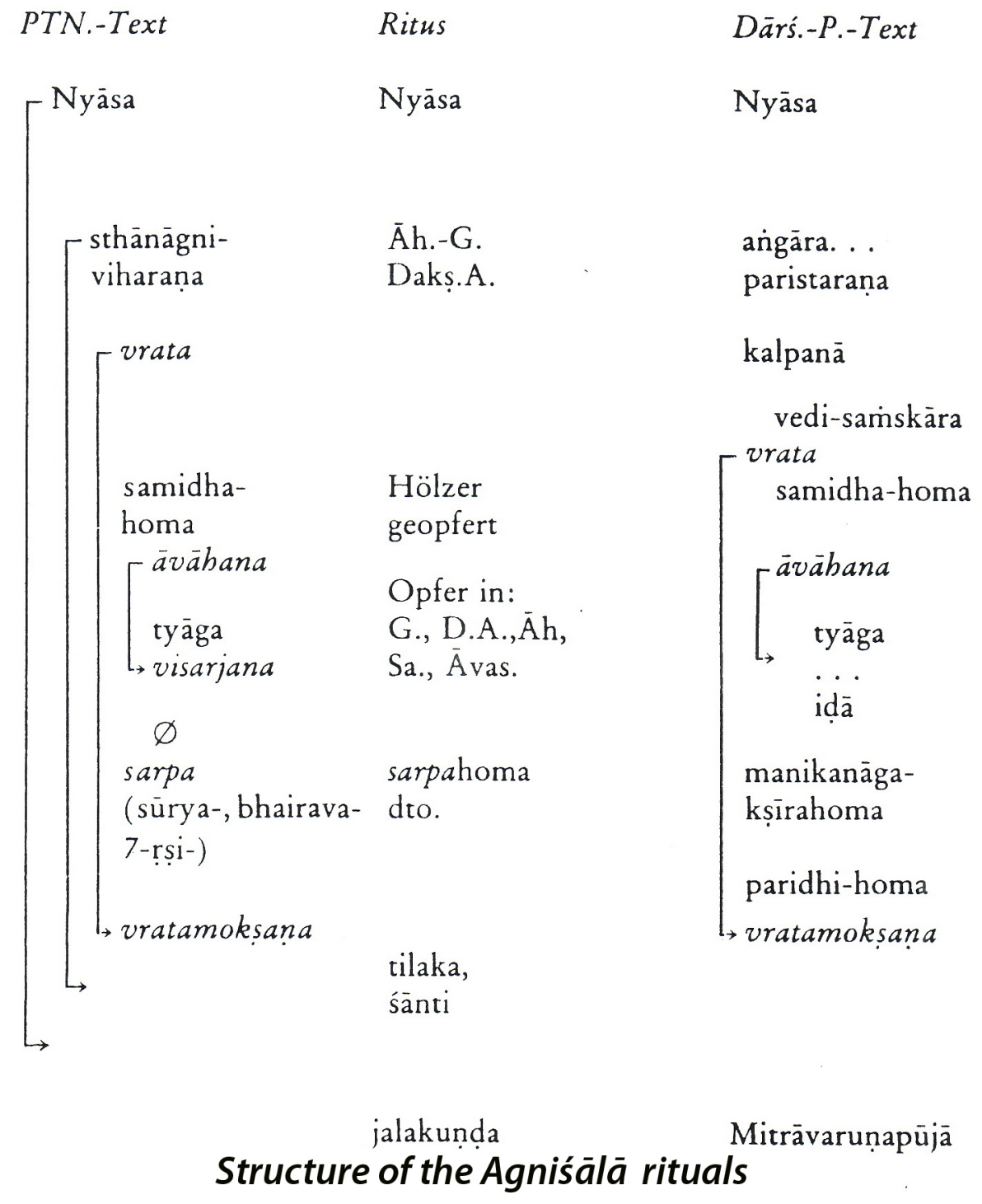

Āh.-G. angāra. . .

paristarana

kalpanā

vedi-samiskāra

vrata

ävähana

tyāga

.

manikanāga-

kșìrahoma

paridhi-homa

vratamokșana

Structure of the Agniśālā rituals

\section{Veda + Paśupatināth}

Patan text

Nyāsa

1. Preparations:

- milking,

- cleaning of the ground

2. Actions at the fires:

- grass strewn around the fires

- water sprinkled around the fires

- water line from the Āh. $\longrightarrow$ Gārh. sthānāgni-

viharana
Ritual

Dārś. text

Nyāsa

Nyāsa 
3. Offering of milk (etc.)

- heating of the milk on the Gārh.

- lighting up with grass,

- paryagni-kriya

- offering into the Gārh., Āh. and for Agni

[[veneration of the fires]

water and similar offerings]]

4. Water and similar offerings

- eating by the yajamāna (sarpa)

- 4 water libations

- offering of wood sticks

5. Veneration of the fires (opt.)

- for the Āh., Gārh.

- for Dakṣ.Agni (manasāa)

Circumambulation of the fires, vrata-vimokṣaṇa vrata

samidha-homa

$\bar{a}$ āhana

$$
\text { tyāga }
$$

visarjana kalpan̄̄

vedi-

samskāra

vrata

wood

offered

samidha-

homa

$\bar{a}$ āhana

offering into G. D.A.

Āh., Da. Āvas. sarpa sarpahoma (Sūrya, Bhairava, (same) 7-Ṛṣi)

vratamokṣạ̣a manikanāga-kșīrahoma

vratamokṣana

tilaka, śānti

jalakuṇḍa mitrāvaruna$p \bar{u} j \bar{a}$

Paddhati adds:

offering into the $\bar{A} v a s$.

Abbreviations and meanings:

Paś.

Paśupatināth Agnihotra

PTN

Patan Agnihotra

Dārș.

Dārśapaurṇamāsa (New and Full Moon sacrifices)

sthānāgniviharạa distributing the holy fire from the Gārhapatya

$\overline{\mathbf{A} h .}$

Āhavanīya Gārhapatya fire 


\begin{tabular}{|c|c|}
\hline D.A., DakșA. & Dakṣināgni fire \\
\hline paristaraṇa & strewing around the fire \\
\hline kalpaṇā & uttering of the sacrificial desire \\
\hline vrata & observance during sacrifice \\
\hline vedi-samskāra & rituals relating to the Vedi \\
\hline vedi & trapezoidal structure between the 3 fires \\
\hline samidha-homa & offering of wooden sticks into the fire \\
\hline $\bar{a} v \bar{a} h a n a$ & calling the deity \\
\hline paryagni-kriya $\bar{a}$ & rite in which the offering substance is carried around the fire \\
\hline Sa. & Sabhya fire \\
\hline $\bar{A} \mathbf{v a s .}$ & $\bar{A}$ vasathya fire \\
\hline tyāga & 'giving up': actual offering into a fire \\
\hline visarjana & 'sending away' of the god \\
\hline$i d \underline{a}$ & offering share, sprinkled with melted butter; eaten by participants \\
\hline yajamāna & ,sacrificer/sponsor'; mostly do not identical with the priest \\
\hline sarpahoma & sacrifices for snakes \\
\hline Sūrya & sun god \\
\hline Bhairava & terrible form of Śiva \\
\hline kșīrahoma & offering with milk \\
\hline \multicolumn{2}{|c|}{ paridhihoma offering with 'surrounding sticks' } \\
\hline vrata(vi)mokṣaṇa & abandonment of the sacrificial observance \\
\hline tilaka & $\begin{array}{l}\text { Nepali: } t \bar{k} k \bar{a} \text {, or, dot of red sindura paste put on the forehead; } \\
\text { or, at the Agnihotra, made from ashes }\end{array}$ \\
\hline śānti & pacification ceremony \\
\hline
\end{tabular}


manas $\bar{a}$

jalakuṇda

bhikșa 'in mind,' that is, without sacrificial formula (mantra)

altar for the jala (water) Nāga

'begging of food ', here: distribution of offering remnants

(prasāda) to bystanders, animals, spirits, etc.

2.7. Even a very cursory comparison of the Vedic rules --here given according to the Kātyāyana Śrautasūtra of the White Yajurveda-- with the execution of the ritual by the Agnihotri of Paśupatināth allows to recognize that both forms are almost identical. All actions are found that deal with the fire, the actual offering into the fire of milk, melted butter, etc., and finally, the various water libations for the gods, ancestors, 7 Rṣi and Agni - all without any changes over the past $2 \frac{1}{2}-3$ millennia. Remembering my first personal impressions, I may say that one cannot deny this ancient ritual an effect emanating from its simple solemnity. It is all the more remarkable that one has followed the prescribed form for so long, as generally the Vedic tradition in Nepal is not as strong and vibrant as in South India. It is particularly noteworthy that the Agnihotri underlined that he had never seen the text of the Kāty.Śr.S. or its commentary, and that, instead, he carried out the ritual just according to family tradition. He referred to the extensive worship of the fires at the end of the ritual, especially that of the Sabhya fire, as a family tradition, as a supplement to the actual offering. He certainly is right as the Agnyupasthāna is indeed expressly allowed as optional in the Veda and described in great detail, while a detailed worship of the $4^{\text {th }}$, the Sabhya fire, is not mentioned. It is only in the medieval Paddhati that a sacrifice (homa) to the Āvasathya fire has been appended. That this is indeed a new departure is immediately apparent to the viewer through the rite of yogic prānāya ama, the holding of the breath and breathing through the left or right nostril.

2.8. Let us now turn - leaving aside the two Vedic revivals of Thamel / Kumārīgal -- to the Agnihotra of Patan. Unfortunately, the textual situation is not yet as clear as desirable because the actual text used in the Agnihotra is not yet available. ${ }^{39}$ However, we have a full text that deals with all forms of the Agnihotra-related rituals: the Agnihotra-vidhāna of $1433 \mathrm{CE}$. In this manuscript, first the establishment of the fires, the special yearly devotion (pavamāna, pāvaka, śuci) and then, fol.s 28-84, the New and Full Moon ritual is described in great detail. This fundamentally still follows the Vedic rite, but it already has many later additions (Mitrāvaruṇapūjā!). ${ }^{40}$

It then says, in the subsequent morning and evening Agnihotra (sāyamprātarhoma): $:^{41}$

nyāsa- sthānāgniviharạ̣a - vratagrahaṇa

\footnotetext{
$39<$ See above n. 21 for the filming of the MSS> -- Cf. P. Dumont 1939: § 80, and Devayājñika Paddhati in: KŚS 1933: $127 \mathrm{f}$.

${ }^{40}$ See $\$ 2.13$, and notes 17,42 .

41 See below, $\$ 2.11$.
} 
pūrvavat, akșa (?)-vațana-lokapālārcanah, ${ }^{42}$ sarvatra pūrvavat samidhahomah $\mid$... Manike arja ${ }^{(?)}$-vaṭana ${ }^{43}$-lokapālārcanam paurvavat |... vratamokṣaṇam ... | pradakṣinga $1^{44}$

Some mantras are inserted into these specifications. Therefore, this is an abridged version which relies on the prakrti of the Dārśapaurṇamāsa that precedes it. Actually, the individual actions largely agree with each other, as a comparison of the columns "Agnihotra (PTN)" and "Dārśapaurṇamāsa (PTN)" shows, -- that is, apart from those that are typical for the New and Full Moon sacrifices such as: vedi-saṃskāra (creating the Vedi by drawing furrows, bestrewing, etc.), producing, baking, and distribution of the kapālas, the $i \underline{a} \bar{a}$ butter slices, as well as post-Vedic additions such as bali, stotra, mitrāvarunapūjā.

This strange dependence is not found in the Veda, where the Agnihotra and the Dārśapaurṇamāsa are treated as a separate rituals. I in my opinion, this can be explained by the ancient Vedic rule (ĀpŚS 6:15:10 sqq., KS 6.6., MS 1.6.10) that an Agnihotra is not to be offered for a Kșatriya because he is violent and oppresses Brahmins (KŚS 4:15:16). However, if one wants to offer for a Kṣatriya (such as for the king, KŚS 4.15.16-19), then only for one who performs the Soma ritual and who himself performs the Agnihotra at new and full moon (ĀpŚS 6:15:15). On the other days, the main sacrificial priest (Adhvaryu) is to celebrate, i.e: the king must theoretically take part as the yajamāna on new and full moon days; on the other days only the Adhvaryu needs to be present, as quasi-yajamāna. It may be that the emphasis on the Dārśapaurṇamāsa is based on these rules. Or, according to another provision, the yajamāna (i.e. the Adhvaryu) only offers at new and full moon; in turn, the daily homa secondarily resulted from the Dārsapaurṇamāsa associated with it.

Whatever may be the case, even the replacement of milk offerings by ghee, grains (or: a rice mess, Soma) can already be found in the Veda (ĀpŚS. 6.15.8 ad 6.6.4): one who wants, like a king, 'fiery force' (priestly reputation), destruction of his opponents, fulfillment of every desire, a capable son. In in any case, the form of the offerings (use of grains) indicates that the king is the ritual sponsor.

In any case, the actual execution of the daily Agnihotra corresponds perfectly to the provisions of the MS of $1433 \mathrm{CE}$, as a comparison of columns "PTN: text + ritual" indicates; obviously, this table has seriously been simplified.

The ritual takes about an hour, but it is often extended a great deal by women who come to offer their $p \bar{u} j \bar{a}$. The ritual thus includes several hundred individual actions that are simply confusing, if observed without an underlying scheme.

\footnotetext{
${ }^{42}$ Not to be confused with the Grhya ritual (see above $\$ 1.5$ and note 34 . The ritual discussed here has clear Śrauta trains; this probably concerns just a medieval confusion of terms, such as: sāyam/prätar[agnihotra]-homa/ yāga.

${ }^{43}$ Not yet clear to me; even the reading is not certain: akșa/arja/akra- at this and other passages.

$<$ Does it stand for ärja- 'straight' or rather, for ärya-vata- 'honorable tree', i.e. the

Mitravaruṇa/varana tree?>

${ }^{44}$ Probably to be translated: "nyāsa (projection of the god); carrying apart (i.e. spreading to the other fires) of sthānāgni ('continuation-fire', which should be extinguished = Gārhapatya, cf. Pet. Dict. column 1320, sub d.), or: "fire of the place" = of the Agniśālā); taking up of the observance, as shown previously (namely in the Dārśapaurṇamāsa, etc.; worship the guardians of the world (and?) ... everywhere as before: offering of the fire sticks into the fire; at the Manika (altar?); worship the guardians of the world as before, releasing the observance, clockwise circumambulation.
} 
2.9 Even during an initial, superficial consideration of the ritual structure, one's attention is immediately drawn to the introduction of a fixed vrata scheme: the sponsor or the priest have to submit to a particular observance which varies according to the ritual. Its purpose frequently is ritual rebirth: the sponsor must be silent, shave his hair, clench his fists; he receives new clothes that are identified with the amnion; he may only drink milk: these actions reflect the prenatal and early childhood stage. All of this is not as clear ${ }^{45}$ in the Vedic Agnihotra, and it originally was not even necessary as it concerned a sun spell. However, followoing the model of other rituals such as the Dārśapaurṇamāsa, Soma, etc., and the Purāṇic-Tantric homa, ${ }^{46}$ a clear vrata scheme (better, a dīkṣā) was introduced, which encloses the main part of the ritual. The Agnihotra thus follows the typical Indian system of nesting ritual elements, a scheme also known from literature (Mahābhārata, Kathāsaritsāgara etc.). ${ }^{47}$ This procedure cannot be discussed here in detail, however, it is useful to keep it in mind when other parts of the ritual will be taken up.

Another insert clearly is the $\bar{a} v \bar{a} h a n a$, already mentioned: the summoning of the god Agni, who is identified with the sun:

agnir jyotir, jyotir agnih svāhāa (VS 3.9) "The light is Agni, Agni is the light, svāhä." In other Vedic recensions this is even more obvious:

agnir jyotir, jyotih sūryah ... "The light is fire, the sun is the light."

The summoning and the worship of the god is followed by his 'dismissal' (visarjana), the medieval designation derived from a $p \bar{u} j \bar{a}$ term. ${ }^{48}$ This occurs immediately after the end of the ritual, when the worship of the fires takes place and they have been pushed together by hand, in order to make them last overnight as burning embers, at least in the case of the Gārhapatya. Agni will be "reawakened" in the morning, as the texts state.

Just like with the Agnihotra of Paśupatināth so also at Patan, the worship of the fires is appended to the main ritual. In both cases, this is clearly a post-Vedic development, perhaps due to the separate representation of the Agnyupasthāna in the Sūtras: whatever followed the actual Agnihotra was now also appended in practice. In both forms of the Agnihotra, this devotion has been extended a great deal. In Patan it takes place in front of the Jalakunda, thus in front of the place of the snakes (jalanāga, Mani(ka)nāgaräja) -- this does not concern a fire, after all.

\footnotetext{
${ }^{45}$ Cf. however, the Paddhati on KŚS 4.15.5 und Dumont 1939: $§ 76$.

${ }^{46}$ Dealt with by Witzel 1984a, cf. note 48.

${ }^{47}$ Cf. on this, Witzel 1984; Staal, in my view, depicts this, not quite accurately, based on the family tree scheme that has been popular, since the middle of the $19^{\text {th }}$ century in philology and linguistics. However, this concerns (sets of) pieces fully interchangeable (under certain conditions) that can be inserted into each other, much like the well-known Russian or Japanese kokeshi dolls. The same is found in Pānini's grammar (where the conditions are more complicated, see for example the Tripādī!) in the rite, and the in the study of the Veda (avāntaradīkșā, see Veda in Kashmir, ch. V). This may well be regarded as one of the more typical arrangements and forms of thought in India (besides ring composition, concatenation, etc.) - Probably the first mention of such an idea in the secondary literature is found in Louis Dumont, who however has taken this over from his African student R. Apthorpe, s . Dumont ${ }^{2}$ 1979: 398 ff.; see Thieme, StII 8/9 , 1982: 12.

${ }^{48}$ Note, however, the opposite concept of āvahana already in Vedic; for example, devatānām $\bar{a} v \bar{a} h a n a m$ in the Dārśapaurṇamāsa, cf. Hillebrandt 1879: 84 (agnim agna āvāha, somam ā3vaha...).
} 
2.10. Now we have arrived at a very interesting point. We know that the snakes, such as their king Karkoțaka, play a major role in the mythological prehistory of the Kathmandu Valley. Just like Kashmir, the valley is said to have originally been covered by a lake (which is now affirmed by geology). Special worship of snakes therefore expected. They have their own festival in the monsoon, Nāga Pañcamī, which is also carried out at the Agniśālā. Both in the Agnihotra as well as at the Dārśapaurṇamāsa, there is an additional Sarpahoma or Mạ̣ināga(rāja)-kṣīrahoma, an offering to the snake king Maṇināga (often: Manināga, Manika). ${ }^{49}$ This occurs precisely at the time of a water libation to the snakes in the Vedic Agnihotra: Āp.ŚS 6.12.4, after eating the remains of the offerings by the yajamāna and after water libations to the deva, pitr!̣, 7 Rși, agni prthivikkrt, the offerer cleans the sacrificial spoon with water and grass, and then offers in the different directions of the sky with the formulas "for the snakes, you; animate the snakes"; "revive the snakes and ants"; "animate the other creatures than the snakes" ;"revive the serpent deities!"50 These mantras are not found in KŚS, but with ĀpŚS. and (partially) in HirŚS, MānŚS., ĀśvŚS. ${ }^{51}$

Interestingly, in this ritual a blending with the operation of other Veda schools has taken place, which raises the question of the compilation of the Yajurvidhāna of $1433 \mathrm{CE}^{52}$ In the end, this Vedic detail probably is the origin of the extensive worship of snakes in this ritual. Methodically, this is of great interest. Without the Vedic or the medieval texts we would readily assume that the cult of Maṇināga was a purely local Nepali tradition. We now are no longer allowed assume that; anyhow, we now have to refer to Maṇināga, who is attested earlier in Orissa, where he was venerated by Maitrāyaṇiya-Brahmins. ${ }^{53}$ But how was the name Maṇināga(rāja) derived? Maṇināga, in association with Maṇicūdua, is not an unknown quantity in Nepal. As a later Bodhisattva, he was king of Sāketa (Ayodhya) and according to legend, he wore a jewel (mani) on his head. His beneficial actions are reported well in literature. ${ }^{54}$ Local legend has it that he carried out a nirguna-yajña on the Manicūr mountain north of Bodhnāth/Bhaktapur. The following place names are derived from his name:

Mạ̣icūọa-giri (the same mountain)

-linga (in Gyāneśvar?)

-rohiṇī

-talāva

-yogin̄̄ (in Sankhu, cf. Wright 1972: 90): Bajrayoginī

-caitya

-dhārā

\footnotetext{
${ }^{49}$ With the typical non-observation of retroflex sounds in Newari.

${ }^{50}$ Thus Caland's translation; the text has: sarpebhyas tvā sarpān jinva, sarpān pippilikā jinva, sarpetarajanān jinva, sarpadevajanān jinva.

${ }^{51}$ See Dumont 1939: 63 und Index of the ritual actions, p. 219, No. 138-141; Caland 1921: 191, translation of ĀpŚS 6.12.4; cf. also Vait.S., Dumont 1939: 208.

${ }^{52}$ Whose origin is still open to question; the colophons always read: brahmokte yajurvidhāna agnihotre ... prathamo dhyāyah an similar. - I have found nothing in the Brahmapurāṇa; brahmokta 'proclaimed by Brahma' could indicate a very general origin or point to a relationship with the Atharvaveda (Brahmaveda). The mantras, however, agree with the Vājasaneyi Saṃhitā.

${ }^{53}$ See S. N. Rajaguru 1974, Vol. I, 2: No. $23,27$.

${ }^{54}$ Maṇicūọāvadāna, Svayambhupurāṇa, in Newāri: Maṇicūẹāvadānoddṛrta (ed. S. Lienhard); adaptation in the Lokānanda-Nātaka etc.; summary of the legend according to this drama with M. Hahn 1979: 53 ff.; last treated by H. Brinkhaus 1980: 284 with n. 19.
} 
-gaṇeś

-mahākālā

-manoharā (river) $=$ Maṇimatîn $^{55}$

-kumāra

-maṇdapa = west of Mangal Bazar, Patan

-gal-bhatța (Palace of Patan)

cf. also Maṇināgātțika, ${ }^{56}$ in a Licchavi inscription of c. 750 CE (see Witzel 1980, StII 5/6:

323,324 notes 61,83 )

In another variant (Wright 1972: 104) the stone would have been hidden in the linga of Gyāneśvar, and would have fled from there into the river Prabhāvatī (Nakhu), which also plays a major role in the founding legend of the Agnihotra of Patan.

Gyānesvar (Hādigaon) probably was the capital of Nepal during the Licchavi period. ${ }^{57}$ We notice that one always tried to connect the ancient capitals with their Agnihotra locations:

Mātātīrtha $\sim$ Patan, ${ }^{58}$ Gyāneśvar $\sim$ Patan (Nakhu),

and in contrast, an origin from India, from the land of the 'great tradition':

Sāketa (Ayodhyā) --> Manicūḍa mountain --> Nakhu (Patan)

Mithilānagara (Simraongarh --> eastern Bhaktapur --> northwestern Bhaktapur ${ }^{59}$

The importance of the Maṇināga for the Agnihotra is already indicated in the introductory verse of the manual of $1433 \mathrm{CE}$ : brahma viṣnuḥ sarudrāya pāvakosatyarūpiṇe Manikonāganāthāya-namah. Similarly, in the inscription at the Agnišālā of Patan: ... maṇikonāgarājōya yajñarūpāya te namah..$^{60}$

2.11. A comment on a development typical for Nepal may be inserted here. Both at the beginning of the ritual, sometimes in the midst of the ritual, and in particular at its end, a small red wooden figure, standing before the Āhavanīya, is particularly revered. According

\footnotetext{
${ }^{55}$ So Wright 1972: 104, where, however, the correct form is found in the note: nirargada/nirargalayajña: 'a ritual that opnes all bolts', that is: one where the offerer is one of absoluter generosity (cf. the Vedic Sarvamedha ritual, Kaṭha Upanișad 1.1, PB 6.7.15; cf. sārgaḍa- 'bolted up' ŚB, argala,bolt' (Raghuvamśa). In the sacrifice of the Manicūda legend, he has to give away, finally, at the request of Brahmins (!) the gemstone ingrown into his head, which is portrayed with horrible details.

${ }^{56}$ On the origin of the Manoharā river (Maṇimatī), s. Brinkhaus 1980: 276 f., with n. 18; Maṇimaṇḍapa-Vihāra = No. 105 in Gutschow-Shakya, JNRC 4, p. 167, 173: located west of Mangal Bazar.

${ }^{57}$ See Manadhar 1977, Gutschow 1977, Witzel 1980.

58 See above, $\$ 1.2$.

${ }^{59}$ See above, $\$ 1.2$.

${ }^{60}$ Why the grammatically incorrect form Maniko is used in both cases is not apparent to me. It cannot be a local form (without sandhi), as otherwise quite Manika, Maṇika.nāga. etc. appear regularly.
} 
to the priest and already in the MS of $1433 \mathrm{CE}$ it is called Mitravaruṇa, e.g.: mitravarunam $\bar{a} d \bar{a} y a, . . . ~ m i t r \bar{a} v a r u n a s t h \bar{a} p a n a m$.

Actually, this concerns two gods, Mitra and Varuṇa, Vedic Mitrāvaruña(u). As is well known, only Varuna has survived in post-Vedic times, though not as a king of the gods but as the lord of the ocean, a little important position in the pantheon. However, at Patan this divine pair suddenly resurfaces, after 2000 years without any supporting textual evidence. Now, there is many a tradition in India that has existed 'under the surface' for a long time, or that has lived on without textual mentioning or that has deliberately not been mentioned; as such it has developed further, only as to show up in a text rather suddenly. However, in the present case, the reason will be a different one.

In the founding legend of the Agnišālā it is reported that the 'Varuṇa' tree in the courtyard grew from the walking stick of the Agnihotri. The Mitrāvaruṇa figure is made from its wood, and the priest walks, at each Agnihotra, to the varana tree, the Miravaruṇa figure in his hand, and worships the tree with a tilaka.

One may therefore assume that a connection has been made between the varana tree of the first Agnihotri and the ocean god Varuna; this is one of quasi-etymological nature, as has been very common ever since the Vedic times. (Note also that many sacrificial implements are to be made from varana wood, Kāty.Śr.S. 1.3.32).

The background is this, among others: the location of the Agniśālā is closely related to water: not only that it was here that earlier on there was the confluence of Nakhu (Prabhāvatī) and Bāgmatī rivers (thus, a Triveṇī, including also the heavenly Sarasvatī, the Milky Way, ${ }^{61}$ it also is here that the jalakuṇda of the serpent god Maṇināga is found. Therefore even today the ground is particularly humid, one says, and in fact one can clearly see traces of rising groundwater on the fire altars. Once even the Vedi (which is incidentally called samudra) had been flooded; however, this failed to extinguish the

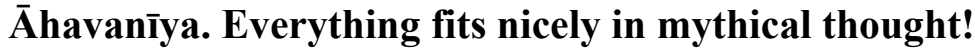

On the other hand, Indian texts such as the Mahārāșțian fortnightly Pakșayāga, ${ }^{62}$ too, include the worship of Varuna. Indeed after the worship of the Mahāvedi and the mandala gods, and after the installation of the kalaśa, Varuṇa is worshipped on the covering plate of his vessel.

2.12. Returning to the structure of the ritual, two frames have become clear:

- The frame of the actual Agnihotra (vratārambha --> vratamokṣana)

- The frame of the main oblations (agny-āvāhana --> visarjana).

Another, all enclosing frame may be seen in the carrying forward (agni-viharana) and in the final pushing together of the wooden sticks and the ashes of the fires; however this is not as pronounced here as in the Vedic ritual. A framework that includes the entire ritual, is established by the nyāsa, the evocation of the god in meditation at the beginning of the ritual and the identification of his body parts with those of the priest, and upon completion, the god's sending off.

\footnotetext{
${ }^{61}$ See Witzel 1984b.

${ }^{62}$ See Śuklayajurvidhāna, ed. K.P. Anna Sastri 1943: 684; this book does not match the Yajurvidhāna the MS of 1433, but it is similar to other vidhānas (Rgvidhāna, transl. Gonda, etc.), where the use of Mantras for sorcery is taught, etc.
} 
This ultimately results in a structure equivalent to the Buddhist and other Hindu Tantric homas ${ }^{63}$ with a dual summoning of the god: first, by meditation and infusion into the fire of the conventional (samaya), mentally created god, then the evocation (avāhana) of, as the Buddhists would say, the lokottara or jǖanadeva, and their union. ${ }^{64}$

Apparently it is only at this one location in Indian culture, that the Vedic Agnihotra ritual has undergone a development to a typical Tantric ritual, -- this is a real and special local development. $<$ For a detailed interpretation of this Tantric form of the Agnihotra see Witzel 1992>.

2.13. Many other details of the Patan Agnihotra, and in particular of the New and Full Moon sacrifice, and other rituals cannot be discussed any further here. According to the MS of $1433 \mathrm{CE}$, there are the following.

Establishing new new Agnihotra
kuṇḍalakșaṇa
maṇikādāna
agnyādhāna + pāvaka-iștị
manthāna-sthāpanāgni ${ }^{\circ}$
pāvaka-pavamāna-śuci-ișți

Offerings

dārśa-paurṇamāsa

sāyamprātar-(homa)

vaiśvadeva-(homa)

anvārambhạ̣a-iṣṭi

dina-ișți

Yearly cycle

Āsvina / Viśākha:

\author{
death of the Agnihotri ${ }^{65}$ \\ kāyīvana-ișți (?) \\ śava-iști \\ preta-iṣți \\ sañcayana-ișți \\ yamavadha-ișți \\ āvāha-sakhyādāna (paśubandha-iṣți)
}

\footnotetext{
${ }^{63}$ Cf. for example Jayākhyā-Samhita 1967: 132-158 (agnikāryavidhāna) - with ten saṃskāras too (p. 141) for the tantric fire as well like the ones for Mitrāvaruṇa, see also above, note 49. A superficial characterization of the ritual in R.C. Hazra 1975: 219.

${ }^{64}$ It remains to be seen whether the Buddhist forms of fire ritual have exercised an influence on the Brahmanical (homa, agnihotra) in the Kathmandu Valley. One merely has to observe the fairly frequently occurring designation nirvāna in these rituals and the doubling of the sword, sphya or jnāna-khadga. Even the name suspiciously points to the name of the sword of wisdom of the Bodhisattva Manjuśrī, that it is not used, as the ordinary one, to excavate the Vedi. It is possible that similar ideas underlie the use of the sword by the Agnihotri of Paśupatināth: this has to be explored further.

${ }^{65}$ The deceased is carried on little used, thorny paths to the confluence of the Nakhu and the Bagmatī; vgl. also MS, fol. 67-fol. 82.

${ }^{66}$ Similar to the consecration of a new Macchendranāth figure (Locke 1980: 208-216); at the assumption of office by the new Agnihotri, the new Mitrāvaruna, too, has to undergo the 10 samskāras (MS fol. 7: nāganātha (Mạ̣ikanāga), starting with garbhādhāna via vratabandha (= upanayana) and ending with patnīyojana (who is the patnī here is not clear initially, perhaps the wife of the Agnihotri, as he should carry the fire inside); on the janai pūrnimīa day, Mitrāvaruṇa as all participating Brahmins, the fire altars, etc. receive a new Yajñopavīta (puțikika, whose shape differs from the commonly used one).
} 


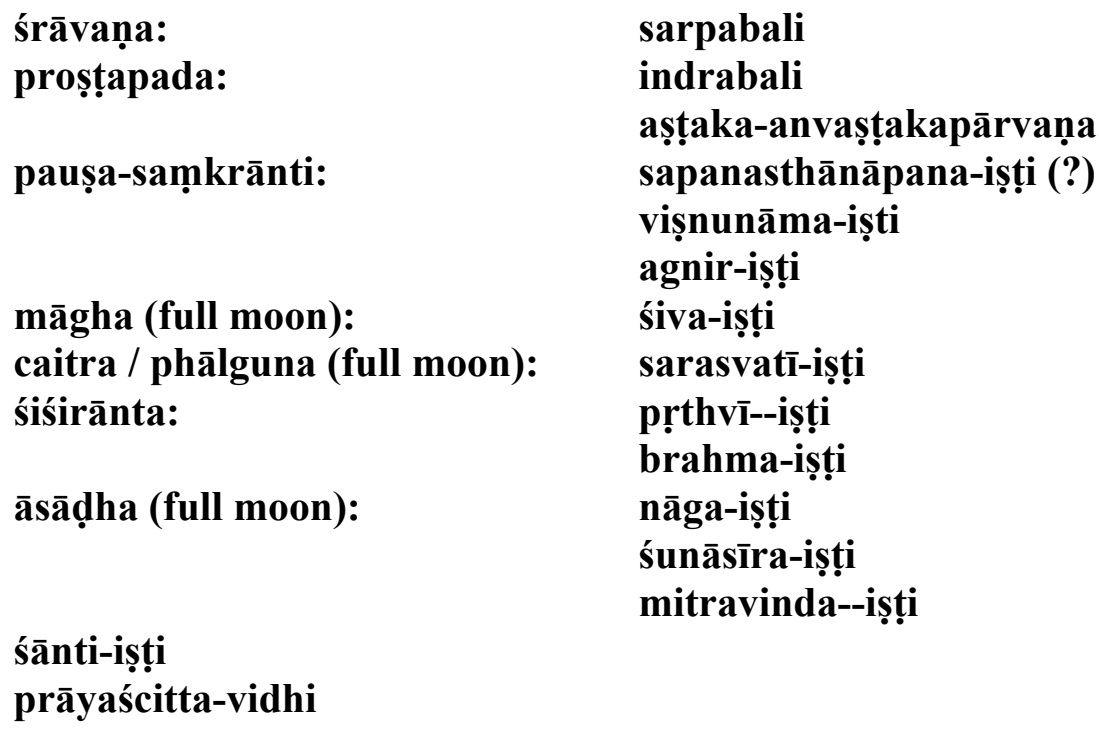

Only two additional comments: when the New or Full Moon sacrifice is carried out every fortnight, next to the Agnihotrin and his wife (= yajamana, yajamānit) the following priests must take part as well: Hotr, Adhvaryu, Brahman, Agnīdh (who are attributed to the RV, YV, AV, Upaveda respectively). However, they appear but rarely: it was only at last year's [1985] Pāvanārohaṇa, that three of the four additional officiating priests showed up. In this particular case, the sequence of the ritual was: Agnihotra - Paurṇamāsa - Pāvanārohaṇa. At other times, only the New / Full Moon sacrifice follows the actual Agnihotra, just as it is prescribed in the Vedas.

Finally, one point is very important: during the offerings to the gods, ancestors, etc., the late Agnihotri clearly mentioned the name of the king - also that of the late King Mahendra-- probably, because he had financially supported this Agnihotra (as well as that of Kumārīgal). It has already been mentioned that the ruler was mentioned, for the first time, in the manual of $1601 \mathrm{CE}$. Thus, an expressive relationship is established between the Agnihotra and its his real yajamāna, the (ruling) king.

\section{SOCIAL POSITION}

3.1. This allows to proceed to the important social context of the ritual and the social position of its priests, for both (or, all its four) forms. The different ethnic or communal affiliations of the Agnihotrins have been discussed earlier: the Rājopādhyāyas represent the oldest, early medieval layer of the immigration of Brahmins into the valley. As very frequently in eastern India ${ }^{67}$ here, too, Kanauj is claimed as their previous home. In Patan, they belong to six clans (kawa) (see M. Allan, Cult of Kumari, p. 42 sqq.), who maintain, just as those from Bhaktapur, to have immigrated from Mithilā, along with King Harisiṃha. The family tradition of a Rājopādhyāya family of Patan goes back for 23

\footnotetext{
${ }^{67}$ Most of the Bengali and Oriya Brahmins trace back their origins to immigrants from Kanauj (oder Mithilā).
} 
generations to a Śaktirāma, ${ }^{68}$ one of Bhaktapur for 20 generations to Ullāsarāja, ${ }^{69}$ thus to c. 1400/1500 CE, a period when many Brahmins immigrated both from central North India ('Kanauj') as well as from Mithilā, and from eastern areas up to Bengal.

The six clans, named after their place of residence, and with additional 'family names,' are the following, according to Allan:

1. Bakanimha, about 25 families, family name: Sukula (cf. note 68)

2. Wala: Paṇdeya

3. Thabu (thus Allan; perhaps more correctly: Bamlāniṃha (Bolima)?: Agnihotri

4. Tadalibi?

5. Nuga: extinct

6. Soniṃha (Solima): Miśra, about 12 families (cf. note 68)

Incidentally, it is doubtful whether this classification is old. The inscription at the Agnimața only speaks of a Guthīī ${ }^{70}$ (dvijapañcāli): Here, too, a Śakti-[Rāma] is mentioned: brahmapuri dvijavara Śakti [...]. (Perhaps this inscription is the source of Hemrāj Śākya's date of 1572 for the Agnimatha: a number [...]2 could still be recognized.) ${ }^{71}$

The Agnihotrins thus seem to belong to the third subgroup. All marriages take place among these five subgroups, nowadays often also outside of town (for example, in Bhaktapur), since the 100 Rājopādhyāya families are divided in just 3 gotras, and have trouble to find brides for their young men. The gotras are: Bhāradvāja, Gārgya, Śāṇḍilya. ${ }^{72}$

The Pūrbe, to whom the other three Agnihotrins (of Paśupati, etc.) belong, came from areas to the east, some clearly from Bengal. ${ }^{73}$ After the conquest of the valley by the Gorkhas (1768/69), they could outflank the Rājopādhyāyas and they supplied the Rājagurus from them onward, up to the Rāṇās. Both groups therefore were in close contact with the respective dynasty. This also applies to the priests who perform the Agnihotra. It has already been mentioned that an old witness of the Agnihotra in Nepal, a fragmentary inscription, is found very close to the old palace of Bhaktapur. Also, the legends about the creation of the first Agnikunda of Patan and of the Agnihotra unequivocally prove a relationship with the palace. Śankaradeva founded both the temple of his (actually, already the Licchavi kings') kuladevatā, Tāraṇīdevī, at Hanuman Dhoka and at the Patan Agnikuṇḍa.

In the MS of $1433 \mathrm{CE}$, I have not found a direct reference to the king; however, in the MS of $1601 \mathrm{CE}$ the king is mentioned (see below): ${ }^{74}$ rājā dharma-vijaȳ bhavatu | prajā sukhinah santu | deśa-subhodayo 'stu ...

\footnotetext{
${ }^{68}$ See Allan 1975: 42 ff. <See now Sharma 1984: 25, inscription at the Agnimatha of the year $[\ldots] 2>$.

${ }^{69}$ See Witzel 1976: 163.

${ }^{70}<\mathrm{A}$ guṭhi (Skt. goșthikā, pañcāli) is socio-religious organization supported by a private or royal donation or by revenue from land $>$.

$71<$ The inscription had further decayed by 1985, and even more so when I last saw it in 2009. Children-bhikșus, as the Agnihotri used to scold them in 1985-- play in the courtyard, where the inscription is set into the surrounding wall; cf. text in A. Sharma 1984: 25; cf. Bajracharya 1999: 31, of $1569 \mathrm{CE}>$.

${ }^{72}$ Witzel 1976: 161, note 13; the late Agnihotri Gurujvālānand was a Bhāradvāja.

${ }^{73}$ See Witzel 1977: 21.

${ }^{74}$ Here printed as seen in the MS.
} 


\section{dvipada-catuspadebhyaḥ śubham bhavatu | sarvvasatvāh sukhinah santu | parjanyah} kālavarșī bhavatu \|

This MS belonged to the famous Rājaguru of Patan, Viśvanāth Upādhya. Some statements can be made about his family and his other relatives. The MS of NS 721 (1601 CE) comes from a time when Patan still belonged to the kingdom of Kathmandu (under King Śivasiṃha, NS 718-39= 1598-1619 CE). Under this king, as well as under his predecessor Ratnamalla (1482- c. 1520 CE), South Indian Brahmins were Rajagurus or chief priests of Paśupatināth. ${ }^{75}$ It appears that the first king of Patan, Siddhinarasiṃha Malla (NS 738788: 1518-1667 CE), deliberately preferred the local Brahmins, in contrast to Kathmandu. Viśvanāth is attested as his Rājaguru at the Kṛ̣na temple, ${ }^{76}$ in NS 757, and then under the next king, Śrīnivāsa Malla (NS 778-805 = 1668-1685 CE). In NS 793, his son Harināth Upādhya performed a kotyāhuti-homa, and in NS 800 a homa at Lele. ${ }^{77}$

Today, the king is mentioned in all the rituals, such as the samkalpa, and, as already mentioned, still King Mahendra. The later point may go back to a donation of the king, probably of a more random nature. All Brahmins report that there had still been many rituals in Rānāa time and under Mahendra, but that in the Seventies there was no money to be had for them. Perhaps that is now, since 1977, about to change in the process of the Sanskritization policy by the education minister Paśupati Śamśer. A first indication is the introduction of a Paurohita examination by the University. ${ }^{78}$

\subsection{What happened to the Agnihotra supported by the Malla kings of Patan after the} conquest of the valley by the Gorkhas? Pṛthvī Nārāyaṇ, especially so as he was planning to set up his capital at Dahacok at the rim of the valley, could have let it continue --'for the good of the country ' as still is said today -just like the kings of Kathmandu and

\footnotetext{
${ }^{75}$ See Regmi 1966 II: 440; another South Indian from Colamandala appears in the long inscription of 1671 CE (Regmi 1966, vol. III: 83): Nārāyaṇa Bhatța, see also no. 30, NS 734 = 1615 CE; cf. also Petech 1958: 70: South Indian Brahmins perhaps since 1178/82 CE, in under Cālukya influence in Nepal; Witzel 1981: $129 \mathrm{sq}$, however, indicates that already around $750 \mathrm{CE}$ and $1036 \mathrm{CE}$ Taittiriya Brahmins (i.e., by that time only South Indians) were present in the Kathmandu Valley. Perhaps they were even earlier immigrants, in early Licchavi or pre-Licchavi time; note names like Godavari, Gokarna! <See now Michaels 1994>.

${ }^{76}$ Particularly this structure in northern Indian style shows another trait of contemporary religious politics: the spread of the Kṛ̣ṇa cult is taken into account. (Cf. the encroachment Viṣṇu names, e.g. in the family tree, Wiztzel 1976, opposite p. 172); at the same time the first inclusion to into the Hindu pantheon of Lokeśvara / Karuṇamaya / Bugadeva is attested (as Macchendranāth), see Matsyendrapadyaśatakam of Nīlakaṇtha, MS dated 1677 CE, see Locke 1980: 282 and 437, cf. Bhāsāvaṃśāvali, II, p. 70. -- On the other hand, note the emphasis on the independent Nepalese tradition (Talejū cult) and the choice of the Rājaguru from the ranks of Upādhya (= today

Rājopādhyāya).

${ }^{77}$ See Regmi 1966: vol. III App. III, p. 71, cf. p. 62 (inscr. of NS 804); Viśvanāth is still mentioned in the year 786, (he lives in Bakanihma!); see Thyāsaphu in Regmi, Vol III, app. III, p. 69 (where also the agnihotra yajamāna, and the Svanihma, Olanihma localities are mentioned). Later Patan Rājopādhyāyas are Siṃhadeva, whose son Harihara Śarmā (Garga Gotra), and his grandson Vaṃśidhara Śarmā, a Agnihotri is attested in 836, who lived in Bamlanimha too (see JNRC 1); one Ratnadhara Śarmā, probably is a descendant, is attested in 876. - Another son of Harihara Śarmā is Parśurāma Śarmā, who became the Rājaguru, and his son Cakrapāṇi Śarmā, who is attested in NS 866, carried out an Ayutāhuti, and lived at Omraniṃha Tol. <More historical data in Sharma 1984, D.R. Regmi 1966 Vol. IV, with inscr. from 1524-1768 CE; and in Bajracharya 1999.>

${ }^{78}$ Cf. Witzel 1977: 36-37.
} 
Bhaktapur (after the division of the Valley into two or three sub-kingdoms) apparently did not install their own Agnihotra, but for example, a special Paśupatināth temple in Bhaktapur, in competition with that of Kathmandu, many Kumārīs, etc. He intentionally reached another decision: as the Rājagurus were no longer chosen from among the Newari speaking Rājopādhyāyas (but also were not freshly imported from India), the Agnihotra was replaced too, however not in Patan, but by a newly founded one (or a reestablished one), and neither at Kathmandu nor at Nuwakot, but at a more or less centrally located place, on the southern edge of the Paśupatināth temple. One would actually have expected a location south of the palace of Kathmandu (or of Nuwakot), because otherwise Brahmins were settled south of the palace.

However, Pṛthvī Narayan selected, apparently deliberately, a Pūrbe Brahmins (Gautam) at Paśupatināth. This family has performed the Agnihotra for 200 years with a support of Rupees 18,000 per year (in 1974/75). This clearly was a political move; he thought centralistically: neither a Gorkha (Kumaĩ), nor a Newar, nor a Maithila became Rājagurus and Agnihotris but one of the Pūrbes, who had recently joined the side of the Gorkhas.

The disappearance of royal patronage and support could not remain without consequence at Patan. First, the Agnihotris must have been secure enough due to their family possessions and the Guthī; in the long run, however, they were at disadvantage in social position and also financially. It is likely that the Agnihotrins then had a brilliant idea: they sought support from among the population of Patan. So far, it was merely stated in the MS of $1601 \mathrm{CE}$ : prajā sukhinah santu etc.; now it became normal that people appeared at the temple at least once per year, on one's birthday, with horoscope and pūjā gifts, and asked to pray for good fortune in the coming year.

However, one is not restricted to this: even today women (but few men) still come to the Agni temple with Pūjā gifts. The Agniśālā, the space of an originally private (or royal) Vedic sacrifice has become a popular Agni temple. Incidentally, this can already be recognized in its external form. It is not one of the usual pagoda style temples with a cella at its center but a dyochem, a "god's house" in its real meaning; only the temples of some popular gods have this form. We actually witness the Vedic god Agni experiencing a secondary flowering, which can be gauged from the constant influx of women appearing for his pūjā. Every morning there are some 20-50 of them. Certainly, Agni is not as popular like, e.g., the Maru Gạ̣eś of Kathmandu, but he also is not a "private god" (as in the Paśupatināth, Thamel, Kumārīgal Agnihotras). It is also important that the visiting women do not worship his iconic form above the entrance on the lower end of the torana, as is often the case (for example, the deity figures at Suvarnadhoka, Bhaktapur). Rather, they worship the aniconic Agni -- the Āhavaniya fire. Here, probably the only place in Indian culture, Agni is still a living god, just as, probably quite secondarily, Mitrāvaruṇa. How far Vedic ideas can sometimes penetrate again is seen in the idea of Agni as "growing inside his house" (RV 1.1.8). ${ }^{79}$ Sometimes non-Newars appear for his pūjā (as I once observed:

\footnotetext{
${ }^{79}$ I heard from a member, trained abroad, of the Agnihotri clan the following account: one says that the fire burning in the Agniśālā burns different intensity if there is a fire somewhere in the city; then, Agni would have left his house (cf. RV (1.1.8 [agnim] vardhamānam sve dame) and, consequently, he would burn in the temple with only a small flame. Now, when in the summer of 1973 the government palace, Singha Darbar, was burned down -- a fire lasting for about a week, which could only be ended by blowing it up -- he says that he, out of curiosity, took a look at the temple to check whether the prophecy was correct --one recognizes his scientific education-- and in fact, Agni burned with
} 
Nepali speakers with a Gurung servant); sometimes even Rāṇās are said to sacrifice. One of them sponsored a big Lakșahoma. Smaller homas for the attainment of special requests are also commissioned by others (Newars, etc.).

3.3. Particularly striking is the role of Yajamānī, the wife of the Agnihotri: she is not, as is the case with the other Agnihotrins, just a static attendant or merely performing a few ritual actions, but she has, like her husband, a kind of "pastoral" function: she takes special care of the women. For example, once she sat in the vestibule of the Agniśālā and comforted a woman who had recently lost her husband and, shortly afterwards, her son as well.

3.4. After losing the high position as Rājagurus 200 years ago, these Brahmins tried, from time to time, to regain social status. For example in the law code of the Rāṇās (valid until 1963), the Rājopādhyāyas ranked after the Nepali Kumaĩ (Upādhyāya), Rājput (Chetri), Jaisi Bahun, Desi Bahun, but before the actual Chetri castes. ${ }^{80}$ They conducted --like one at Bhaktapur and the Buddhist one of the Bajracharyas of Kathmandu-- a special Śāntihoma at the home of a Rājopādhyāya (near Mangal Bazar, Patan) in the summer of 1976 out of fear for a predicted earthquake, and they thus tried to gain the attention of the palace. Such pursuits did not have much success, even if some Rājopādhyāyas were invited, for the first time, to the coronation of King Birendra in the spring of 1975, though not as main actors in the ritual. It looks as if the Rājopādhyāyas are to remain at a relatively low social position -- even if, on the other hand, other Brahmins both envy and despise them because of their Tantric rituals and due to their high number of yajamānas: all Hindus among the approximately 300,000 Newars of the Valley have one of c. 100 Rājopādhyāya families as their Purohita.

Therefore, the hope remains that they retain their special institution of the Agnihotra --and possibly finance it themselves-- and that the tradition does not die, as was feared about 3 years ago ${ }^{81}$ It remains to be seen what impact the Sanskritization policy of

very low flame as he was destroying the government papers floated away for miles, as far away as Swayambhu.

${ }^{80}$ See Witzel 1976: 161, note 12 and compare Höfer 1979.

${ }^{81}<$ That is, c. 1982. In the meantime, the ritual has changed after the death of the Agnihotrin Viṣnujvālānanda in 2004. Bal Gopal Shrestha (email of Dec. 28, 2010) tells me that "when Vishnu Jwalananda passed away [March 27, 2004] we could arrange recording the funeral rituals and follow up rituals afterward. Later, when they installed a new Agnihotri I was there with a Dutch anthropological film maker to record all the procedures ... We plan to make documentaries in four parts from the materials we have recorded. We also have obtained all texts from Patan priests, and even received translation of some Sanskrit texts into Newar language." He adds (Nov. 27, 2012): "Vishnu Jwalananda served as Agnihotra for 22 years and passed away in 2004. Kabijananda Rajopadhyay succeeded him in November 2004, ... passed away in 2007, and Padmaraj Rajopadhyay became the new 
the government may have. The resumption of interest in Sanskrit and everything that is connected with it, under the education minister Paśupati Śamśer (1977). This took place after some 10-15 years of emphasizing a Nepalité (folk songs, dances, theater productions, study of the Karṇāli region by the university), and included the recent introduction of Karmakānda courses at the university (probably along the lines of Baroda, at the beginning of the century), further the establishment of the Sanskrit University at Dang, planned since the days of King Mahendra. It had been regarded as superfluous (i.e. not conducive to economic development), was quickly abandoned, and then founded in the mid-Seventies merely as a 'campus' - also as to get rid of the annoying propaganda of Yogi Naraharināth for a Sanskrit University.

It is interesting to observe that this impulse emanated from a minister who had spent almost all of his school years and had his university education in the West. On other

Agnihotra, but at this occasion no detailed rituals were performed as it was in 2004, because they kept the existing structure [of the 5 fires]. This year, Padmaraj passed away, and Brijendra Rajopadhyay is entering as a new Agnihotra tomorrow. I was told that only a few rituals will be performed, as it was in 2007." --- As I could indeed ascertain during short visit in July 2009, there no longer is a permanent Agnihotrin, but various Rājopādhyāyas serve in turn as to keep the ritual going. Indeed, B.G. Shrestha now confirms (1/1/2013): "After the death of Bishnu Jwalananda, the agnihotra no longer went there everyday ... already when they installed Kabijananda Jwalanand Rajopadhyay as agnihotra in 2004 he was not able to come to Agnimath everyday because of his health and age; other junior Rajopadhyaya began performing daily rituals on his behalf. However, he went there every now and then, especially when there were major rituals. Padmaraj Rajopadhyay ... too was too old to go there everyday; his juniors worked on his behalf performing daily rituals. In a way they are having symbolic agnihotra since Bishnu Jwalananda's successors were unable to carry out daily job there. I don't know yet exactly how present agnihotra Brijendra Rajopadhyay (now 85) does..." He adds (1/5/13) "As it was in the past years, Purna Chandrananda Rajopadhyay (74) is performing daily rituals on Brijendra Rajopadhyay's behalf. Because of his health only occasionally Brijendra Rajopadhyay come to Agnimatha. Other Rajopadhyays only help Purna Chandrananda when he falls sick or busy." -- There is hope, thus, that this ritual will endure the onslaught of modernization for some time to come. - For a summary of the rituals at the Agnimatha, including the installation of a new Agnihotri, see B.G. Shrestha's summary (in Dutch): http://nepalsamaj.nl/index.php?option $=$ content\&task $=$ view\&id=52\& cat $\mathrm{id}=\mathbf{2 5 \&}$ Itemid $=55>($ Jan. 4, 2013). 
hand, the consistent implementation (including the exemption of fees for Sanskrit studies even for high school years) allows to perceive a request of the palace behind al oft this.

During the coronation celebrations, too, one could observe holding on to the old tradition -partially including the Rājopādhyāyas. Unless major political changes should set in, ${ }^{82}$ one can actually reckon with a follow-up of promoting the --as much as possible local-Sanskritic traditions, in short, of all that can serve the 'image' and the consolidation of the 'only Hindu kingdom'.

\section{Summary}

Finally, when an attempt is made to summarize the results of a first comparison of the two main proponents of the Agnihotras in Nepal (leaving the two revivals apart), their original similarities and subsequent individual developments can briefly be presented by a few key words

\section{Patan}

\section{1}

Probably central for all Nepal (of the Malla kingdom), located on the southern edge of Patan.

According to legend, founded by King Śankaradeva (about $1075 \mathrm{CE}$ ).

\section{2}

Execution by Newari speaking Rājopādhyāyas, long-established and assimilated during the Middle Ages.

\section{3}

Tradition of the rite by automatically witnessing, shared experience and by assistance in its execution; more importantly, by written tradition: pure Sanskrit (1433 CE), later on Skt. mixed in with Newari instructions (1600 CE +); succession by Thakali system.

\section{Paśupatināth}

Central for all of Nepal (of the Gorkha/ Shaha dynasty) on the southern edge of the Paśupatināth complex.

Founded by the first king of recently united Nepal, Pṛthvī Nārāyạ̣ (c. 1779)

Execution by Pūrbe Brahmins, relatively late immigrants from India who took over Nepali as their vernacular

Purely oral family tradition; written tradition is not taken even though its existence is known: a 'Vedic' trait

\footnotetext{
$82<$ This prediction has come true with the abolishment of the monarchy in 2008 . Nevertheless, most of the rituals and festivals of the Valley continue unabated, with the President of Nepal having taken over the role of the King; even the staunchly Maoist party leaders are seen to sport a tilaka and as performing or taking part in certain rituals.>
} 
4.4.

Ritual is miśra: Tantric and Vedic elements are strongly intermingled: the frame is Tantric, the core still is Vedic: $n y \bar{a} s a \rightarrow$

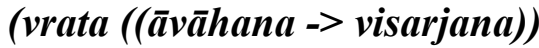

vratavimokṣana) śānti.

Though Agni is aniconic, Mitrāvaruṇa undergoes, as a figure, the samskāras and pavitrārohana.

4.5

3 main fires +2 extra ones

(these are wrongly arranged);

in addition, jala-kunda (of the snakes:

Maṇināga).

Numerous additional gods (Viśvakarman etc). Special veneration of Mitrāvaruṇa, secondarily created from the Varuna

$(<$ varana $)$ tree.

4.6.

Recent developments:

$P \bar{u} j a ̄$ ritual: interwoven and independent from the Agnihotra, Development of Agni into local (and realm's?) god

4.7.

New function of the Agnihotri and his wife as a "pastor" of Patan Partial acceptance by the Gorkhalis (offers by Rāṇā families).
The ritual structure and its sequence is (almost) purely Vedic; vrata $\rightarrow$ (àiga $(($ pradhāna $))$ à̀ga $) \rightarrow$ vrata-vimokșana;

Only - in the opinion of Agnihotrin additional Upasthāna at the Āvasathya fire (which is however is already medieval: Paddhati on the Kāty.ŚS)

3 main fires +2 extra ones;

(these are wrongly arranged)

\section{8.}

The originally North Indian Agnihotra of Patan, that has for centuries been executed in the Kathmandu Valley, and that has increasingly been exposed to local influences, has been replaced by the new dynasty, at the end of the $18^{\text {th }}$ century, by a purely Vedic Ritual, as it was contemporaneously carried about at Benares. The priest was changed as well and he was centrally positioned at the realm's main sanctuary, Paśupatināth. The goal of Pṛthvī Nārāyaṇ obviously was to counterpoise and balance the local Tantric tradition with the transregional 'pure' Vedic tradition (of Benares). (Otherwise, too, he wanted to move away from the local, Newar traditions, customs and usages; this included the plan for a capital just outside the valley. His turn toward the Vedic tradition may ultimately have been 
influenced by a north Indian model: a few decades earlier the Mahārāja of Jaipur had performed the last known Aśvamedha.

\section{REFERENCES}

Allan, M. The Cult of Kumari. Kathmandu 1975.

Atharvaveda-Parišișța, ed. G. M. Bolling and J. v. Negelein. Leipzig 1909.

Bajracharya, Dhanabajra. Lichavi Käl.ko Abhilekh. Kathmandu: Centre for Nepal and Asian Studies, VS 2030 [1974].

Bajracharya, Dhanabajra. Madhyakälin.kā Abhilekh. Kirtipur, Kathmandu: Institute of Nepalese and Asian Studies, VS. 2056 [1999].

Bodewitz, H. Jaiminīya-Brāhmaṇa I, 1-65. Translation and commentary with a study of the Agnihotra and Prānāgnihotra. Leiden 1973.

Brinkhaus, H. References to Buddhism in the Nepālamāhātmya, JNRC IV, 1980: 273-286.

Burleigh, P. A chronology of the later kings of Patan. Kailash IV, 1976, 21-71.

Caland, W. Das Śrautasūtra des Āpastamba. Göttingen 1921, Amsterdam 1924,1928.

Deo, S. B. Archeological Excavations in Kathmandu, Kathmandu: Dept. of Arch./HMG 1968.

Dumont, P.-E. L'Agnihotra. Baltimore 1939.

Dumont, L. Homo hierarchicus, Paris ${ }^{2} 1979$.

Folia Rara, Wolfgang Voigt LXV diem nat. cel. ... dedicata, ed. H. Franke et al., Wiesbaden 1976.

Gutschow, N. Notes on the topography of present day Hādigaon, JNRC I, pp. 89-92.

Hahn, M. The play Lokanandanataka by Candragomin. Kailash VII, 1979, 51-67.

Hasrat, B.J. History of Nepal. Hoshiarpur 1970.

Hazra, R.C. Studies in the Puranic Records on Hindu Rites and Customs. Delhi 1975 [1940]. 
Herdick, R. Neue Kulte in Kïrtipur. In: Formen kulturellen Wandels und andere Beiträge zur Erforschung des Himalaya, ed. B. Kölver and S. Lienhard, St. Augustin: VGH

Wissenschaftsverlag 1986: 249-282.

Hillebrandt, A. Das altindische Neu- u. Vollmondopfer. Jena 1879.

Hillebrandt, A. Ritualliteratur. Straßburg 1897.

Höfer, András. A study of the Muluki Ain, Innsbruck 1979.

Jayākhyā-Saṃhitā, ed. E. Krishnamacarya, Baroda 1967.

Kātyāyana Śrautasūtra, ed. Pt. Vidyādhara Śarmā, Benares (Chowkhamba Sanskrit Ser. 415) 1933.

Kiauta, M.A.J.E. De Toranas van de Tāranidevī-Tempel. [Thesis] Utrecht 1977.

Krick, H. Das Ritual der Feuergründung. Wien 1982.

Lienhardt, S. Maṇicūụāvadānoddṛta : a Buddhist re-birth story in the Nevārī language, edited by Siegfried Lienhard; translated by Hans Jørgensen. Stockholm : Almqvist \& Wiksell 1963.

Locke, J. K. Karunamaya. Kathmandu 1980.

Manandhar, Thakur Lal. Nepal in the Early Medieval Period: Gleanings from the Bendall Vaṃśāvali. JNRC I, p. 83-92.

Michaels, A. and Govinda Tandan .Die Reisen der Götter : der nepalische PaśupatināthaTempel und sein rituelles Umfeld / Axel Michaels; mit einem Beiheft Paśupitakṣetra - maps of Deopatan, with drawings by Harald Fritzenkötter. Bonn : VGH Wissenschaftsverlag, 1994.

Munamkarmi, Lilabhakta. Mallakälin Nepal. Kathmandu 1968.

Narten, J. Die Aməša Spəntas im Avesta. Wiesbaden 1982.

Pant, Mahesh Raj. Pușyābhișeka. JNRC I, 93-109.

Parpola, A. and Kashikar, C.G., Śrauta traditions in recent times, in: J.F. Staal, Agni, Vol. II: 193-251.

Petech, L. Medieval history of Nepal. Roma 1958. <2nd, thoroughly rev. ed., Roma : Istituto italiano per il Medio ed Estremo Oriente, 1984>. 
Pruscha, Carl. Kathmandu Valley, the preservation of physical environment and cultural heritage: a protective inventory / prep. by His Majesty's Government of Nepal in collaboration with the United Nations and Unesco. Vienna: Schroll, 1975.

Rajaguru, S. N. Inscriptions of Orissa by Satyanarayan Rajaguru, curator, Orissa State Museum. Bhubaneswar, Orissa Sahitya Akademi. Bhubaneswar: Gouri Kumar Brahma, 1974 sqq.

Regmi, D. R. Medieval Nepal, Vol.s I-IV. Calcutta 1966.

Śāstri, K. P. Anna. Śuklayajurvedavidhāna (Kātyāyana-praṇīta), Bombay: Nirṇaya Sāgara Press 1943.

Sharma, Aishvaryadhar. Agimmmathah.yā aitihāsik sāmagrī (The historical materials relating to Agnimath). Kathmandu: Puṣpāñjalī Prakāśa Mālā 2, 1984 [in Newari].

Staal, J.F. Agni, the Vedic ritual of the Fire Altar. Vol.s I-II. Berkeley 1983.

Staal, J.F. The Science of Ritual. Poona 1982.

Śuklayajurvidhānasūtra, ed. K.P. Aṇṇā Śāstrī. Muṃbaī: Paṇḍita Nārāyaṇa Mūlajī Pustakālaya/Nirṇayasāgara 1943.

Thieme, P. Meaning and form of the 'grammar' of Pāṇini StII 8/9, 1982, 3-34.

Witzel, M. Zur Geschichte der Rājopdhyāyas von Bhaktapur. Folia Rara. Festschrift W. Voigt, ed. by H. Franke et al., Wiesbaden: Steiner 1976: 147-167.

Witzel, M. On the history and the present state of Vedic tradition in Nepal. Vasudha XV, No.12, 1977, 17-24, 35-39. http://www.people.fas.harvard.edu/\%7Ewitzel/Veda.in.Nepal.pdf.

Witzel, M. On the location of the Licchavi capital of Nepal, StIl 5/6, 1980, 311-336.

Witzel, M. Materialien zu den vedischen Schulen: I. Über die Caraka-Schule. StII 7, 1981, 109-132; StII 8/9, 1982, 171-240.

Witzel, M. Buddhist forms of fire ritual (homa) in Nepal and Japan. (Summary). 31st CISHAAN (Tokyo-Kyoto), Proceedings, ed. by T.Yamamoto, Tokyo 1984a: 135.

Witzel, M. Sur le chemin du ciel. Bulletin des Etudes indiennes 2, 1984b, 213-279.

Witzel, M. On the origin of the literary device of the "frame story" in Old Indian literature (Summary). 31st CISHAAN (Tokyo-Kyoto), Proceedings, ed. by T.Yamamoto, Tokyo 1984c: 534. 
Witzel, M., Regionale und überregionale Faktoren in der Entwicklung vedischer Brahmanengruppen im Mittelalter, In: Regionale Tradition in Südasien, edited by H. Kulke and D. Rothermund. Beiträge zur Südasienforschung. Heidelberg 1985a: 37-76.

Witzel, M. Die Atharvaveda-Tradition und die Paippalāda Sạ̣hitā. Deutscher Orientalistentag, Tübingen, March 1983, § 11, supplement volume, ZDMG, 1985 b.

Witzel, M. Agnihotra-Rituale in Nepal. In: Formen kulturellen Wandels und andere Beiträge zur Erforschung des Himalaya, ed. B. Kölver u. S. Lienhard, St. Augustin: VGH Wissenschaftsverlag 1986: 157-187.

Witzel, M. Meaningful ritual. Structure, development and interpretation of the Tantric Agnihotra ritual of Nepal. Ritual, State and History in South Asia. Essays in honour of J.C. Heesterman, ed. A.W. van den Hoek, D.H.A. Kolff, M.S.Oort, Leiden 1992, 774-827.

Wright, D. History of Nepal. Kathmandu 1972 (1877).

\section{Manuscripts used}

Kesar Library No. 28. Title leaf: Agnihotradārśapūrṇamāsa, filmed by the NGMPP 1975, Film C 3/8; fol. 87+2, palm leaf., 33 x $4.8 \mathrm{~cm}$., old Newari script (Bhujimo), NS 533 .

Kātyāyanabhāṣe Darśapaurnamāāsya vidhānam. Private possession, Patan, filmed by the author <1985>, Tyāsaphu, 38 fol., title leaf: Agnihotra.yā karma.

Interviews with the late Agnihotri Gurujvālānand (1979). 

Abbreviations
Āp(ŚS) Āpastamba Śrautasūtra
Āśv. Āśvalāyana Śrautasūtra
Hir. Hiraṇyakeśi(Satyāṣāọha) Śrautasūtra
JNRC (Journal of the Nepal Research Centre). Wiesbaden $1977 \mathrm{ff}$.
KŚS Kātyāyana-Śrautasūtra
KS Kaṭha Saṃhitā
MS Maitrāyaṇi Saṃhitā
NGMPP Nepal-German Manuscript Preservation Project (1970-2002)
PB Pañcavimuśa Brāhmaṇa
RV Rgveda Saṃhitā
ŚB Śatapatha Brāhmaṇa
StII Studien zur Indologie und Iranistik
VS Vājasaneyi Saṃhitā
ZDMG Zeitschrift der Deutschen morgenländischen Gesellschaft 